\title{
Economic Development Benefits from Wind Power in Nebraska: A Report for the Nebraska Energy Office
}

E. Lantz

Technical Report NREL/TP-500-44344

Revised June 2009

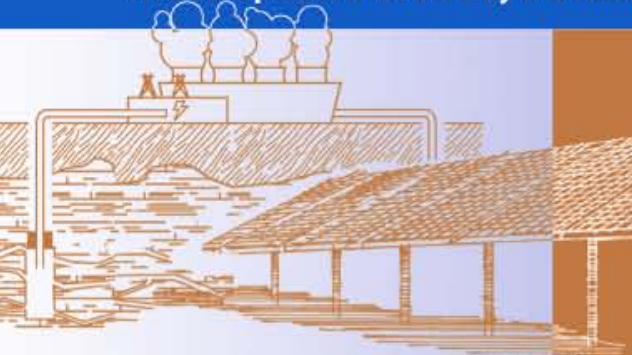




\section{Economic Development Benefits from Wind Power in Nebraska: A Report for the Nebraska Energy Office}

Technical Report NREL/TP-500-44344

Revised June 2009

E. Lantz

Prepared under Task No. WER9.8501

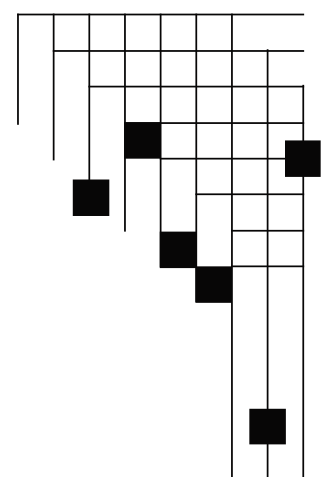




\section{NOTICE}

This report was prepared as an account of work sponsored by an agency of the United States government. Neither the United States government nor any agency thereof, nor any of their employees, makes any warranty, express or implied, or assumes any legal liability or responsibility for the accuracy, completeness, or usefulness of any information, apparatus, product, or process disclosed, or represents that its use would not infringe privately owned rights. Reference herein to any specific commercial product, process, or service by trade name, trademark, manufacturer, or otherwise does not necessarily constitute or imply its endorsement, recommendation, or favoring by the United States government or any agency thereof. The views and opinions of authors expressed herein do not necessarily state or reflect those of the United States government or any agency thereof.

Available electronically at http://www.osti.gov/bridge

Available for a processing fee to U.S. Department of Energy and its contractors, in paper, from:

U.S. Department of Energy

Office of Scientific and Technical Information

P.O. Box 62

Oak Ridge, TN 37831-0062

phone: 865.576 .8401

fax: 865.576 .5728

email: mailto:reports@adonis.osti.gov

Available for sale to the public, in paper, from:

U.S. Department of Commerce

National Technical Information Service

5285 Port Royal Road

Springfield, VA 22161

phone: 800.553.6847

fax: 703.605.6900

email: orders@ntis.fedworld.gov

online ordering: http://www.ntis.gov/ordering.htm 


\section{Acknowledgements}

The author would like to thank the following individuals for their support and assistance throughout the course of this work: Larry Flowers, director of the National Renewable Energy Laboratory's (NREL's) Wind Powering America program, for funding and supporting this analysis; Michael Milligan (NREL) for analytical support and review; and Suzanne Tegen (NREL) for reviewing early versions of this report. As well, thanks to John Hansen of the Nebraska Farmers Union for sharing the nuances of the wind energy market and policy landscape in Nebraska and Ken Lemke of the Nebraska Public Power District for reviewing the final report.

\section{Authors note on the updated report}

This updated report has been issued because the prior version mislabeled the equity payments shown in Table 2. Data were labeled as total equity payments while in reality these values represented the annual equity payments (from operating the total installed capacity expected under each scenario). In order to accurately reflect the total equity payments, these values should be increased by a factor of 20 to account for the expected operating lifetime of each wind facility. Because these data were mislabeled, this also resulted in the miscalculation of the reported annual equity payments noted on page 16 of the prior report.

Rather than issuing this updated report with the updated values for the equity payments, further reflection has led the author to remove all reporting of equity payments. This decision was made because it was determined that this metric is not adequately explained in the body of the report and the author believes that removing these values from the reported data will reduce confusion when interpreting the results.

Please be aware that this update does not affect any other totals or values reported in the work. One category of data was merely mislabeled in the final results so all other results remain as they were originally reported.

E. Lantz 


\section{Table of Contents}

Report Summary....................................................................................................................................

Wind Power: A Growing and Maturing Industry with a Role for Nebraska ...................................

Quantifying Nebraska's Economic Development Impacts ......................................................................4

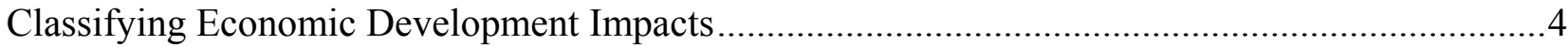

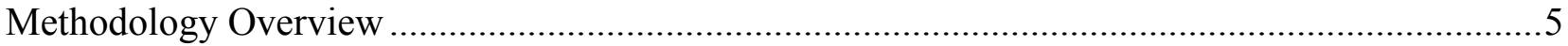

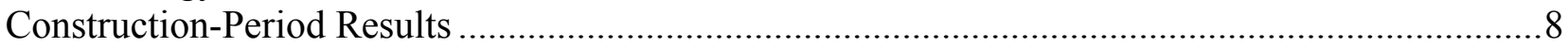

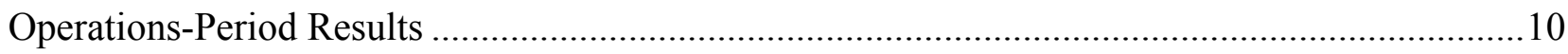

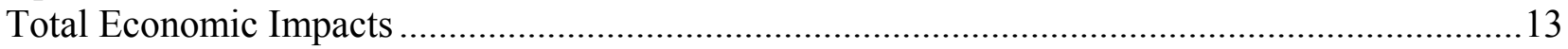

Analysis and Conclusions ..............................................................................................................13

Bibliography .................................................................................................................................17

Appendix I: Detailed Modeling Methods.............................................................................................AI-i

Appendix II: Supplemental Discussion............................................................................ AII-i

Wind Energy and Public Power Expanded........................................................................... AII-i

Modeling and Analytical Considerations ...........................................................................

Manufacturing and Economic Development ……............................................................ AII-iii

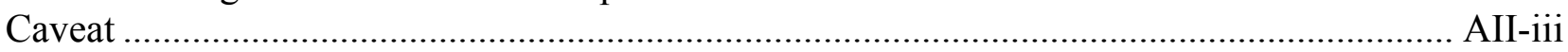

Appendix III: JEDI Model Inputs....................................................................................................AIII-i

Appendix IV: Detailed Results for Traditional Low and C-BED High scenarios (1,000 MW

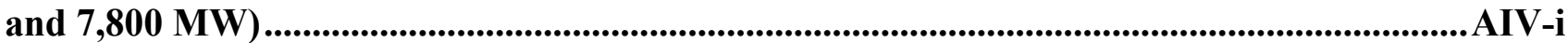

\section{List of Figures}

Figure 1. Direct, indirect, and induced construction period jobs from 7,800 MW of wind energy construction in Nebraska (For a summary of key assumptions associated with individual scenarios, see Table 1).

Figure 2. Short-term jobs supported by manufacturing and construction of 1,000 MW of wind power in

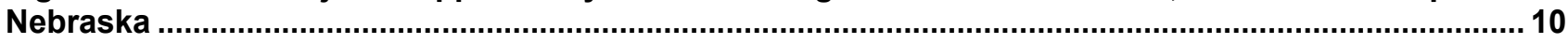

Figure 3. Direct, Indirect, and Induced long-term jobs from operating wind power plants built in accord with the $20 \%$ Wind Energy by 2030 report; up to 7,800 MW.

Figure 4. Annual economic output from operating wind power plants built in accord with the $20 \%$

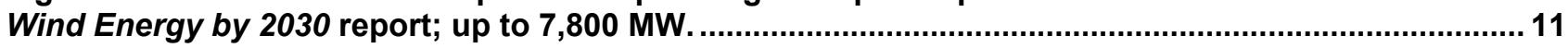

Figure 5. Long-term jobs resulting from operations of 1,000 MW of wind power ...............................12

Figure 6. Annual economic output from operations and maintenance at wind power plants ...............12

\section{List of Tables}

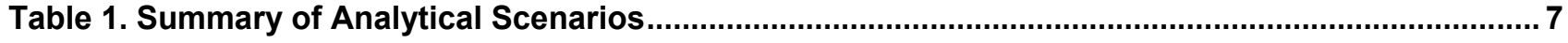

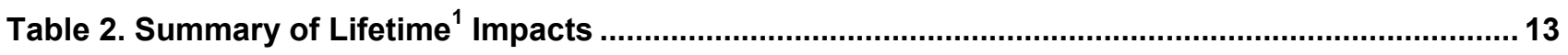

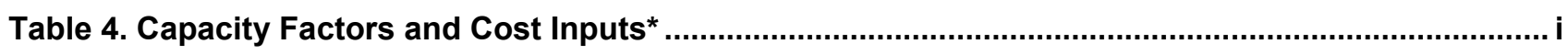

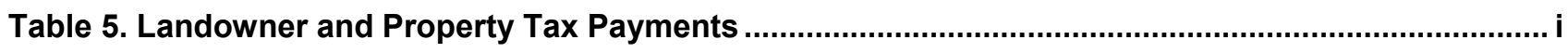

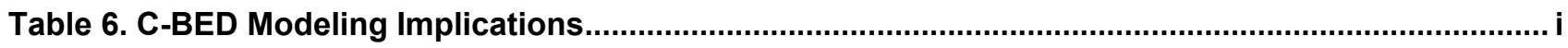

Table 7. Percentage of Project Expenditures Directed to Nebraska.......................................................... ii 


\section{Report Summary}

Wind power constituted more than $35 \%$ of new U.S. electric generating capacity in 2007. Common drivers of wind power include Renewable Portfolio Standards (RPS), the federal production tax credit (PTC), and rural economic development benefits. Continued expansion of the wind industry into Nebraska would bring new employment and economic development to Nebraska and the country. This report by the National Renewable Energy Laboratory (NREL) focuses on the economic development impacts that would result in Nebraska from development and operation of wind power in the state as envisioned in the U.S. Department of Energy's (DOE's) report 20\% Wind Energy by 2030. Under the national 20\% wind scenario, 7,800 megawatts (MW) of new wind power is added in Nebraska. ${ }^{1}$ A practical first step to building 7,800 MW of wind is completing 1,000 MW. We also include the estimated economic impacts to Nebraska from building 1,000 MW of wind power.

Economic impacts are estimated with NREL's Jobs and Economic Development (JEDI) Wind model and include direct, indirect, and induced impacts. Direct impacts accrue from expenditures in the wind industry. ${ }^{2}$ Indirect impacts accrue in supporting industries as a result of increased demand for basic goods and services. ${ }^{3}$ Induced impacts result from reinvestment and spending by direct and indirect beneficiaries. ${ }^{4}$ In some cases, depending on the structure of the local economy, indirect and induced impacts may be greater than direct wind industry impacts.

Jobs values are defined as construction-period jobs, operations-period jobs, and average employment impacts. All jobs totals include direct, indirect, and induced jobs. Construction-period jobs are defined as short-term, 1-year jobs, and include those jobs resulting from Nebraska-based construction and manufacturing. ${ }^{5}$ Operations-period jobs are full-time jobs that exist for the operating lifetime of the wind power facility; typically this is 20 years. Average employment is defined as the average jobs - direct, indirect, and induced - supported by wind development and operations over the full construction and operations period. This period is defined as 40 years for the $7,800 \mathrm{MW}$ built in accord with the national $20 \%$ wind scenario and 22 years for the $1,000-\mathrm{MW}$ analysis. All results are expressed as ranges and are based on the four possible development scenarios foreseen for Nebraska. Primary variables contributing to the range of impacts are the role of Nebraska manufacturing, the prevalence of Nebraska project ownership, and the availability and utilization of Nebraska labor.

\footnotetext{
${ }^{1}$ As of October 2008, Nebraska had $117 \mathrm{MW}$ of installed wind capacity.

${ }^{2}$ Direct beneficiaries generally include wind energy developers, construction companies, operations and maintenance personnel, landowners, and equity investors. For additional examples, see Text Box 1, Text Box 2, and page 7 of this report.

${ }^{3}$ Indirect beneficiaries include material and component suppliers as well as accountants and legal personnel.

${ }^{4}$ Induced benefits are often associated with increased business at local restaurants and retail establishments. In short, they include all increases in economic activity driven by increased spending of direct and indirect beneficiaries.

${ }^{5}$ Construction-period jobs are inherently short-term. One construction-period job is defined as one 2,080-hour working period or one full-time job for 1 year. The annual construction-period employment impact varies depending on the length of the construction process and the number of individuals employed. Two construction-period jobs can be satisfied by one worker working 2 years or two workers working 1 year. Manufacturing jobs are included in construction-period jobs as 1-year jobs because Nebraska-based wind development will only support manufacturing jobs during the development and construction process. However, unlike the construction industry, manufacturers may employ fewer total employees for a longer period of time (i.e., ten workers for 10 years as opposed to 100 workers for 1 year).
} 
The results of this analysis indicate that the development and construction of 7,800 MW of wind energy in Nebraska by 2030 will support 20,600 to 36,500 construction-period jobs ${ }^{5}$. Operating $7,800 \mathrm{MW}$ of wind energy is estimated to support 2,200 to 4,000 operations-period jobs. ${ }^{6}$ On average, Nebraska's economy is estimated to see a boost in economic activity ranging from $\$ 140$ million to $\$ 260$ million $^{7}$ annually from construction-related activities between 2011 and 2030. An additional annual economic contribution of $\$ 250$ million to $\$ 442$ million is estimated from operating 7,800 MW of wind capacity. Annual land-lease payments to Nebraska landowners during operations of 7,800 MW are estimated to range from \$27 million to \$32 million, and annual property tax payments by wind farms are expected to be on the order of $\$ 29$ million.

Assuming development and operations over a 40-year period, the average employment impact from building 7,800 MW in Nebraska is 1,600 to 2,925 full-time jobs. ${ }^{8}$ Total lifetime economic output to Nebraska is estimated to be $\$ 7.8$ billion to $\$ 14.1$ billion when assuming a 20 -year operations life for all wind facilities.

Economic development impacts from constructing 1,000 MW of wind power in Nebraska are estimated to be approximately 2,300 to 4,200 construction-period jobs ${ }^{9}$ with a total constructionrelated economic output of $\$ 260$ million to $\$ 514$ million. Operating 1,000 MW of wind power is estimated to support 264 to 515 full-time jobs over the operations-period ( 20 years) and contributes $\$ 30$ million to $\$ 57$ million annually in economic activity. Land-lease payments are estimated to be $\$ 3.5$ million to $\$ 4.1$ million annually, and local property tax revenues are estimated to be $\$ 3.7$ million annually.

\footnotetext{
${ }^{6}$ Operations period jobs are long-term jobs that last for the life of the wind facility; typically this is 20 years.

${ }^{7}$ All dollar values are 2008 dollars.

${ }^{8}$ Assuming 7\% of turbines (by cost) installed in Nebraska are Nebraska-built in the low case and $14 \%$ are built in Nebraska in the high case.

${ }^{9}$ Again, these are short-term jobs. One construction-period job is equivalent to one 2,080-hour working period.
} 


\section{Wind Power: A Growing and Maturing Industry with a Role for Nebraska}

The wind industry ${ }^{10}$ has become one of the most rapidly growing power generation industries in the country. In 2007 , wind generating capacity growth was $45 \%$, and wind energy constituted $35 \%$ of all new U.S. power generation capacity, second only to natural gas (Wiser and Bolinger 2008). Further, in the second quarter of 2008, the United States became the world leader in energy produced from wind power (Real de Azua 2008). A variety of factors drive the current high pace of growth, including state Renewable Portfolio Standards, the federal Production Tax Credit, and the economic competitiveness of wind power (Wiser et al. 2007 and 2008).

The rapid emergence of the U.S. wind industry has just begun to have an impact on Nebraska. Two proposed projects, highlighted in Text Box 1, demonstrate a few of the impacts Nebraskans can expect from wind industry growth in their home state during the next 12 months.

\section{Text Box 1: Expected Direct Impacts from Proposed Nebraska Wind Projects}

\section{Crofton Hills Wind Farm - $42 \mathrm{MW}$ \\ Bloomfield, Nebraska \\ Expected online date: 2009}

- Stably priced electricity for approximately 13,000 Nebraska residences

- Lifetime local property tax payments of $\$ 3.2$ million

- Work for 50 construction workers

- 4 permanent, direct, O\&M jobs

- Landowner lease and project revenue payments in excess of $\$ 300,000$ annually

- Project revenue payments to Nebraska individuals and businesses that are at least $33 \%$ of gross power production revenues

\section{Elkhorn Ridge Wind Energy Project - 82 MW}

Bloomfield, Nebraska

Expected online date: year end 2008

- Stably priced electricity for approximately 25,000 Nebraska residences

- Total investment of $\$ 140$ million with initial estimates that $15 \%$ (\$21 million) will be invested specifically in Nebraska goods and services

- Lifetime property tax payments of $\$ 5.7$ million

- Land-lease payments in excess of $\$ 325,000$

- More than 100 construction workers over the 9-month construction period

- Project revenue payments to Nebraska individuals and businesses that are at least $33 \%$ of gross power production revenues

Compiled by the author from developer press releases

\footnotetext{
${ }^{10}$ Here defined as businesses related to the development, construction, and operations of wind power plants and including all associated manufacturing industries that produce wind-power-related components.
} 
However, Nebraska's excellent wind resource - among the top ten in the country - places it in prime position to capitalize on continued growth in the industry. This potential is highlighted in the recent U.S. Department of Energy (DOE) report 20\% Wind Energy by 2030, ${ }^{11}$ where Nebraska could build more than 7,800 megawatts (MW) of wind power in a national scenario where $20 \%$ of U.S. electricity consumption is met by wind energy. ${ }^{12}$

Achieving this high level of wind energy development would have a dramatic impact on Nebraska's economy ${ }^{13}$; and while it is an ambitious goal, such development is not unprecedented. Since the late 1990s, more than 5,500 MW of wind power have been installed in Texas, and the state added 1,708 MW in 2007 alone (Wiser and Bolinger 2008). Further U.S. installations have doubled, growing from 10,000 MW to more than 20,000 MW in the past 2 years (Clendinen 2008). Nevertheless, building approximately 7,800 MW of wind power would require a concerted effort and significant investment. Additional transmission will also be required to reach this level of wind development. However, this analysis does not consider the economic impacts of building new high-voltage transmission development; nor do we consider the electricity rate impacts or integration costs associated with wind energy.

The primary analysis of this report is based on the 7,800-MW capacity to be built in Nebraska under the $20 \%$ wind scenario. However, to better appreciate the near-term impacts that can be gained from building wind power, this report includes an analysis of the economic development impacts of building 1,000 MW of wind energy.

\section{Quantifying Nebraska's Economic Development Impacts}

\section{Classifying Economic Development Impacts}

Local impacts accrue in Nebraska when spending on new wind farms is directed to Nebraska-based individuals, institutions, government, and businesses. Wind energy resources in Nebraska are generally abundant in rural areas. ${ }^{9}$ Harvesting wind energy resources presents a prime opportunity for rural communities to capture investment and increase revenues.

Impacts are classified in this report as direct, indirect, and induced impacts. Direct impacts (see Text Box 2 for examples) go to companies engaged in development, construction, and operation of wind farms. Direct beneficiaries from wind energy include project developers, road builders, concretepouring companies, construction companies, turbine erection crews and crane operators, operations and maintenance personnel, landowner lease recipients, and project owners who receive revenues from power sales.

\footnotetext{
${ }^{11}$ This report and additional literature are available at http://20percentwind.org.

${ }^{12}$ This is still only a fraction of the full Nebraska wind energy potential. Nebraska high-resolution wind maps show 764 $\mathrm{GW}$ of Class 3 wind is available in the state and $157 \mathrm{GW}$ of Class 4 wind is available. www.windpoweringamerica.gov.

${ }^{13}$ This report only considers the economic development impacts from building and operating wind energy. We do not consider the electricity rate impacts or the integration costs associated with wind energy. For additional information on integration costs, refer to http://www.uwig.org/.
} 


\section{Text Box 2: Wind Power's Direct Local Impacts \\ Weatherford Wind Energy Center - 147 MW \\ Weatherford, Oklahoma \\ Owned by FPL Energy \\ Power Purchaser: American Electric Power \\ Date Online: 2005}

- $\$ 300,000$ annually in land-lease payments

- $\$ 17$ million in lifetime property tax payments

- 150 construction workers

- 6 permanent O\&M workers

- City economic development manager estimates local benefit at greater than \$1 million during 2005

- Local construction firm received nearly $\$ 300,000$ in revenue from the project

- United Rentals revenue increased $\$ 70,000$ during a 5-month period when heavy construction equipment was required

- FPL has made commitments of:

- $\$ 150,000$ to the local school district

- More than $\$ 75,000$ to the City of Weatherford

○ $\$ 30,000$ to Southwestern Oklahoma State University

Compiled by F. Oteri, NREL (www.windpoweringamerica.gov)

Spending on wind projects also has indirect impacts from supporting industries that are driven by the increase in demand for goods and services from direct beneficiaries. Indirect beneficiaries include construction material and component suppliers, accountants and legal personnel who assess project feasibility and negotiate the contract agreements, banks financing the projects, wind turbine component manufacturers, and manufacturers of maintenance equipment and repair parts.

Finally, induced impacts result from reinvestment and spending by direct and indirect beneficiaries. These induced impacts are often associated with increased business at local restaurants and retail establishments but also include child care providers and any other entity that is impacted by increased economic activity and spending from direct and indirect beneficiaries.

\section{Methodology Overview}

NREL's Jobs and Economic Development Impacts (JEDI) Wind Model (Appendix I) was used to estimate economic development impacts. This input-output model relies on 2006 industry multipliers. ${ }^{14}$ To capture the potential range of impacts, which depend on future developments in the industry and the amount of time over which the primary analysis is based, this analysis applied four economic development scenarios for Nebraska. These scenarios were derived from wind projects under development in Nebraska and interviews with Nebraska power and wind industry stakeholders. ${ }^{15}$ The four scenarios cover high and low Nebraska economic impact analyses for two

\footnotetext{
${ }^{14}$ Industry multipliers are derived from the changes in economic activity associated with changes in demand for goods and services in the year in which the multipliers were calculated. As such the industry multipliers are based on a snapshot of the economy from 2006. Industry multipliers can and do vary over time. Uncertainty associated with these results is increased by multiplier variability over time.

${ }^{15}$ Industry stakeholders include wind developers active in the state, the Nebraska Public Power District's (NPPD's) economic development group, NPPD's renewable energy project managers, and the Nebraska Farmers Union.
} 
dominant project ownership models. Two dominant ownership models were considered because of Nebraska's Community-Based Energy Development (C-BED) policy (Text Box 3) and uncertainty about its role in future development.

\section{Text Box 3. Community Development, Wind Energy, and Public Power Working Together through C- BED}

In 2007, Nebraska signed into law a category of wind development focused on local communities and so named Community-Based Energy Development, or C-BED. The C-BED development model supports Nebraska's public power model by facilitating wind power development in Nebraska that is capable of capturing the Production Tax Credit (PTC) by providing the greatest rural economic development impacts to the state ${ }^{1}$ and providing the potential for lower-cost wind energy. ${ }^{2}$ As such, C-BED projects are perceived as a benefit to public power because they enhance public power's prerogative to support rural development ${ }^{3}$ and support least-cost energy development while encouraging Nebraska ownership in wind energy projects and maintaining consistency with Nebraska's traditional citizen-owned public power system. ${ }^{4}$

${ }^{1}$ This is shown in this analysis.

${ }^{2}$ C-BED projects qualify for state sales and use tax exemptions (Nebraska Revised Statutes 77-2704.57). This has the potential to reduce capital costs if all other cost parameters are competitive with projects that are not eligible for the sales and use tax exemption. In Nebraska, sales and use tax is often in the range of $6 \%$ to $7 \%$. Depending on what is purchased in Nebraska, this benefit could be very significant. Further lower development costs may result from less opposition to C-BED projects because of their increased impacts for local communities.

${ }^{3}$ Public power districts have a state mandate to consider economic development when making development decisions. By promoting rural economic investment and development, C-BED projects help meet this mandate. This analysis will demonstrate how much greater economic development results from C-BED projects as opposed to those that rely on traditional development structures. This mandate is highlighted in the Nebraska Revised Statutes $70-625$ and $70-625.01$.

${ }^{4}$ C-BED projects require $33 \%$ of wind farm gross sales revenues to flow to qualifying Nebraska individuals or businesses. Frequently this is accomplished by obtaining local equity to finance a portion of the project, and it ensures that Nebraskans continue to maintain a stake in new power ceneration facilities in the state

Under the first ownership model, it is assumed that C-BED projects become the dominant development model for wind in Nebraska. ${ }^{16}$ This increases the economic development impacts of wind projects by ensuring that a portion of the profits from a wind farm remain in Nebraska and by potentially encouraging increased reliance on local labor, capital, and materials. In addition, these projects are given financial and property rights incentives to facilitate development, which may enhance their ability to provide lowest-cost wind energy (Nebraska Revised Statutes 70-1901-1909; 77-2704.57). ${ }^{17}$ (For a detailed discussion of the attributes of C-BED and how C-BED projects are modeled, see Text Box 3 and Appendices I and II).

The early precedent for C-BED dominance is strong. The first two projects to successfully negotiate power purchase agreements with the Nebraska Public Power District, since the policy went into effect, are C-BED projects. Nebraska wind industry stakeholders frequently believe that C-BED is generally the more favorable development model because of its ability to support and fulfill public power mandates (Text Box 3). ${ }^{18}$

\footnotetext{
${ }^{16}$ This scenario assumes $80 \%$ of projects built in Nebraska are C-BED. This is believed to be a conservative scenario for a C-BED-dominant scenario due to the preferred financial and property rights treatment reserved for C-BED projects. Some Nebraska stakeholders believe that more than $90 \%$ C-BED development is a likely future for Nebraska.

${ }^{17}$ In addition, Nebraska utilities are required by statute to evaluate C-BED projects when considering new renewable energy generation. Annual reports detailing these efforts are filed and posted on the utility Web site (Nebraska revised statutes 70-1905 and 70-1906).

${ }^{18}$ Including lowest-cost energy, consideration of economic development, and specific consideration of C-BED projects for renewable energy development.
} 
Nevertheless, it remains to be seen how large a role C-BED projects will play in the long term. The second dominant ownership model assumes C-BED projects only have a marginal role in wind power development. This development trajectory is labeled Traditional Development and is based on the popular Independent Power Producer (IPP) model that has been applied throughout the country.

High and low scenarios for each dominant ownership model are included to capture the range of development impacts that are likely to result when considering the availability and cost of local labor, local manufacturing capacity, and local raw materials. High and low scenarios reflect variability in the percentage of Nebraska goods and services that are used on wind power projects in the state (Table 1). (For detail on the variability between modeling parameters for the high and low scenarios, see Appendices II and III).

Table 1. Summary of Analytical Scenarios

\begin{tabular}{|c|l|c|c|c|}
\hline & \multicolumn{1}{|c|}{ Scenario Description } & $\begin{array}{c}\text { Projects } \\
\text { Designated as } \\
\text { C-BED (\%) }\end{array}$ & $\begin{array}{c}\text { Average } \\
\text { Construction } \\
\text { Local Share }\end{array}$ & $\begin{array}{c}\text { Average } \\
\text { Operations Local } \\
\text { Share }\end{array}$ \\
\hline Scenario 1 & C-BED High & $80 \%$ & $25 \%$ & $58 \%$ \\
\hline Scenario 2 & C-BED Low & $80 \%$ & $15 \%$ & $42 \%$ \\
\hline Scenario 3 & Traditional Development High & $10 \%$ & $24 \%$ & $57 \%$ \\
\hline Scenario 4 & Traditional Development Low & $10 \%$ & $37 \%$ \\
\hline
\end{tabular}

All four scenarios are used to model slightly more than 7,800 MW of additional wind power capacity to be built in Nebraska during the period 2011-2030, as projected in the 20\% Wind Energy by 2030 scenario. The ranges presented here may be interpreted as high and low boundaries to the economic development impacts.

For analyzing the impacts of 1,000 MW, the same four development scenarios presented in the primary analysis are applied with a few exceptions. First, the modeling of 7,800 MW assumes that construction begins in 2011. As such, wind manufacturing facilities are able to be built in Nebraska and become operational prior to the large growth in wind development that is observed between 2011 and 2018 in the national 20\% wind scenario. However, when considering the impacts of building 1,000 MW in the next 1 to 4 years, it is less likely that local blade and tower manufacturing will be capable of supplying significant levels of towers and blades. Nevertheless, the Katana

\footnotetext{
${ }^{19}$ In this case, we assume that only $10 \%$ of the projects built are C-BED. Projects developed in this development trajectory still allow public power entities to capture the value of the PTC. However, this analysis suggests that they may not support the mandate for economic development to the degree that C-BED projects will nor will they qualify for the sales and use tax exemptions available to C-BED projects. These two facets may limit the competitive capacity of traditionally developed projects.
} 
Summit tower manufacturer (noted in Text Box 4) is already producing in the state, and so the high scenarios (C-BED and traditional) assume that $25 \%$ of towers used in this $1,000-\mathrm{MW}$ analysis could be supplied by Nebraska-based tower manufacturing. Low scenarios assume that output from existing tower manufactures is not included in the first 1,000 MW of Nebraska wind development. As well, for the 1,000-MW analysis, current market prices for equipment and maintenance are applied rather than the projected ${ }^{20}$ market prices that are used when analyzing development under the national $20 \%$ wind scenario.

All monetary values are constant 2008 dollars. All totals include direct, indirect, and induced impacts. Construction-period impacts are the total construction-period impacts regardless of the length of the construction period. Annual construction period impacts can be determined by dividing the total construction-period result by the length of the construction period. ${ }^{21}$ Operations-period impacts are annual impacts that last throughout the operating life of a wind power plant; typically this is 20 years.

Jobs values are defined as construction-period jobs, operations-period jobs, and average employment impact. Construction-period jobs are defined as short-term, 1-year jobs, and include those jobs resulting from Nebraska-based construction and manufacturing. ${ }^{22}$ Operations-period jobs persist for the full 20 -year operating lifetime of the wind power facility. Average wind-related employment is defined as the average jobs supported by wind development and operations over the full construction and operations period. This period is defined as 40 years, from the time of first construction to final operations, for the 7,800 MW built in accord with the national $20 \%$ wind scenario. For the $1,000-$ MW analysis, this period is defined as 22 years ( 2 years for construction and 20 years for operations).

\section{Construction-Period Results}

Construction of a single wind power plant often presents a short-term dramatic infusion of money into local communities. However, development of 7,800 MW of wind would require years of construction. Construction-period jobs ${ }^{23}$ resulting from 7,800 $\mathrm{MW}$ of wind farm construction are shown in Figure 1. The average employment impact from construction and manufacturing between 2011 and 2030 is 1,030 to 1,825 jobs. Total economic output from building these wind power plants is estimated to be on the order of $\$ 2.8$ billion to $\$ 5.2$ billion.

\footnotetext{
${ }^{20}$ Projected market prices assume a decline in real prices due to technological advancement, economies of scale, fewer supply chain bottlenecks, and increased industry efficiency.

${ }^{21}$ That is, construction-period time varies from a matter of months to more than a year depending on the size of the development, local topography, contractor availability, etc. If the construction period lasts more than 1 year, annual construction-period impacts may be determined by dividing construction-period impacts by the number of years required for construction.

${ }^{22}$ Construction period jobs are inherently short-term. One construction-period job is defined as one 2,080-hour working period or one full-time job for 1 year. The annual construction-period employment impact varies depending on the length of the construction process and the number of individuals employed. Two construction-period jobs can be satisfied by one worker working 2 years or two workers working 1 year. Manufacturing jobs are included in construction-period jobs as 1-year jobs because Nebraska-based wind development will only support manufacturing jobs during the development and construction process. However, unlike the construction industry, manufacturers may employ fewer total employees for a longer period of time (i.e. ten workers for 10 years as opposed to 100 workers for 1 year).

${ }^{23}$ This value is the total number of 2,080-hour labor blocks or single-year jobs supported by construction and manufacturing.
} 


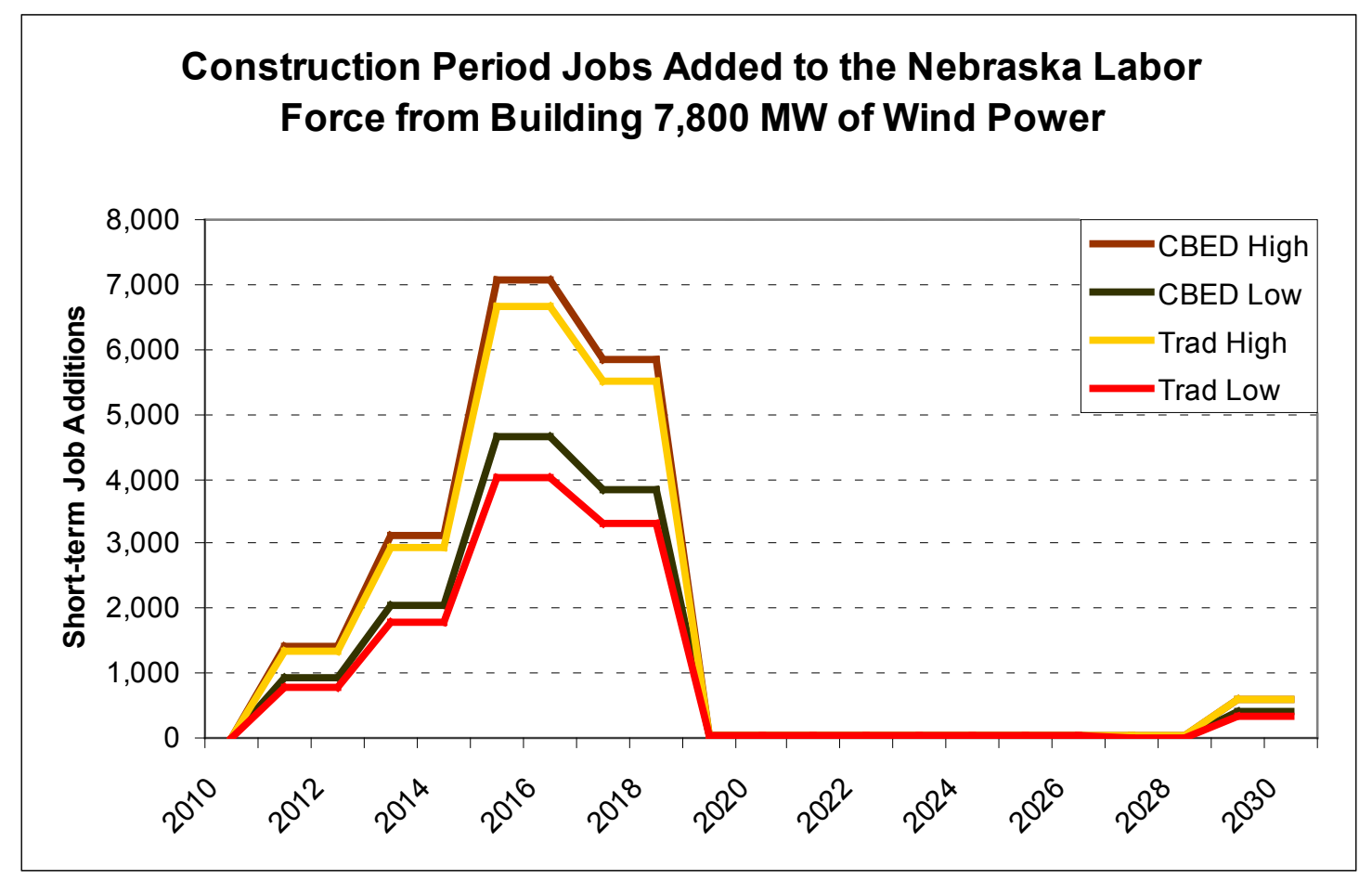

Figure 1. Direct, indirect, and induced construction period jobs from 7,800 MW of wind energy construction in Nebraska (For a summary of key assumptions associated with individual scenarios, see Table 1 and appendix III)

Building 1,000 MW of wind in Nebraska over the next 1 to 4 years will also have large impacts in Nebraska. Construction-period jobs resulting from 1,000 MW are shown in Figure 2. Total construction-period economic output is estimated to range from \$260 million to \$514 million across the four 1,000-MW development scenarios. 


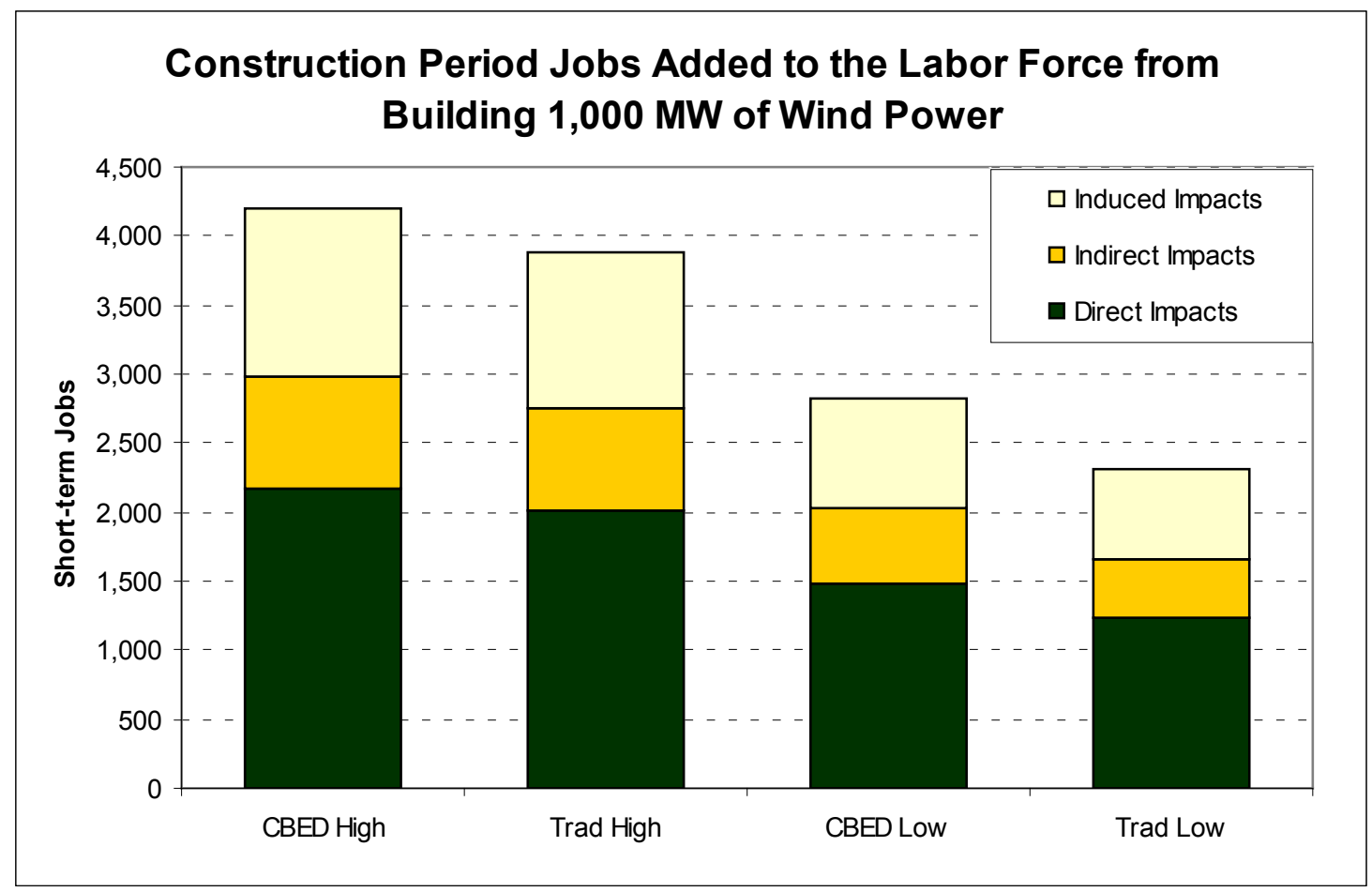

Figure 2. Short-term jobs supported by manufacturing and construction of 1,000 MW of wind power in Nebraska

\section{Operations-Period Results}

Operations-period impacts persist throughout the life of the wind power plant. ${ }^{24}$ In Nebraska, statelevel impacts from operating wind power plants are enhanced by the state's C-BED policy, which encourages project financing to be structured so that revenue from power sales flows into Nebraska communities.

Long-term jobs throughout the development period are shown in Figure 3. This graph represents the growth in jobs supported by operating wind power plants as new capacity is added. By 2018, operating wind power plants are expected to support roughly 2,200 to 4,000 full-time workers for as long as these projects continued to operate, estimated at 20 years. Economic activity from plant operations would follow precisely the same trend as operations jobs. The magnitude of economic activity resulting from operating 7,800 MW is shown in Figure 4.

\footnotetext{
${ }^{24}$ Wind power plants are typically financed on a 20 -year operations period. This analysis assumes operations jobs exist throughout the 20 -year timeframe.
} 


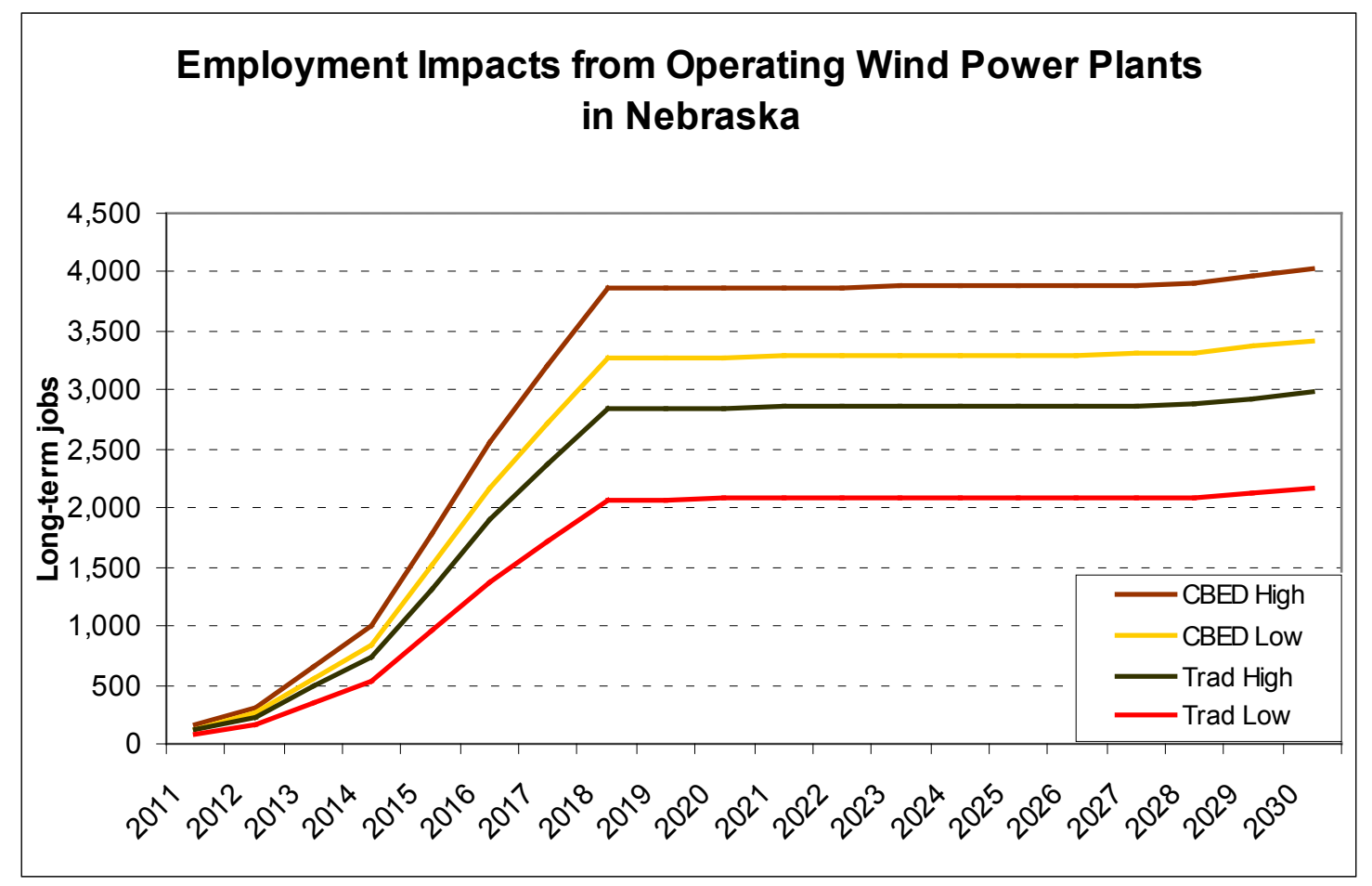

Figure 3. Direct, Indirect, and Induced long-term jobs from operating wind power plants built in accord with the $20 \%$ Wind Energy by 2030 report; up to 7,800 MW

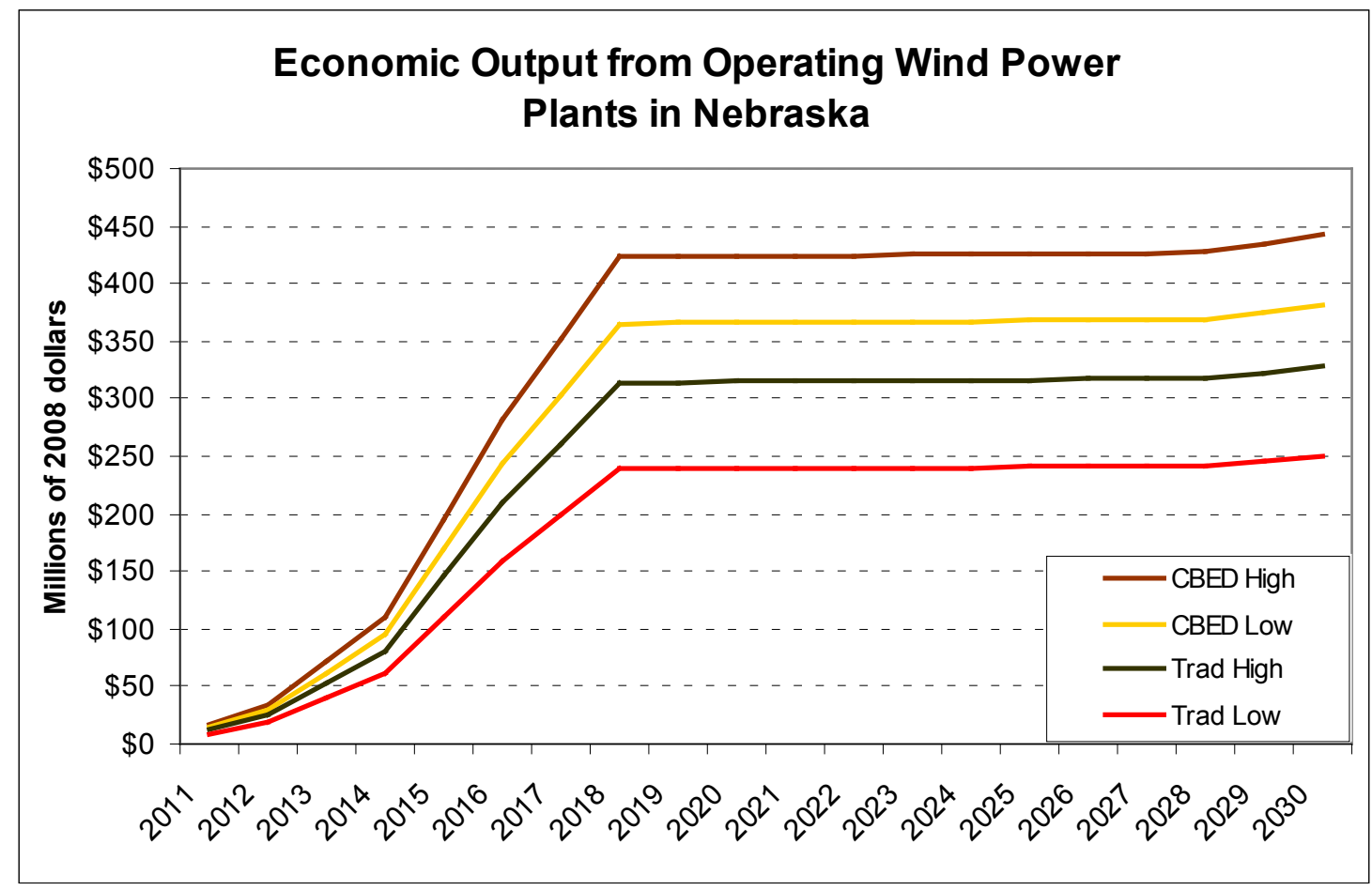

Figure 4. Annual economic output from operating wind power plants built in accord with the $20 \%$ Wind Energy by 2030 report; up to 7,800 MW 
Operating 1,000 MW of wind power also produces noteworthy economic impacts. Long-term jobs supported by 1,000 MW of operations are shown in Figure 5, and the annual contribution to economic activity from operating 1,000 MW of wind is shown in Figure 6.

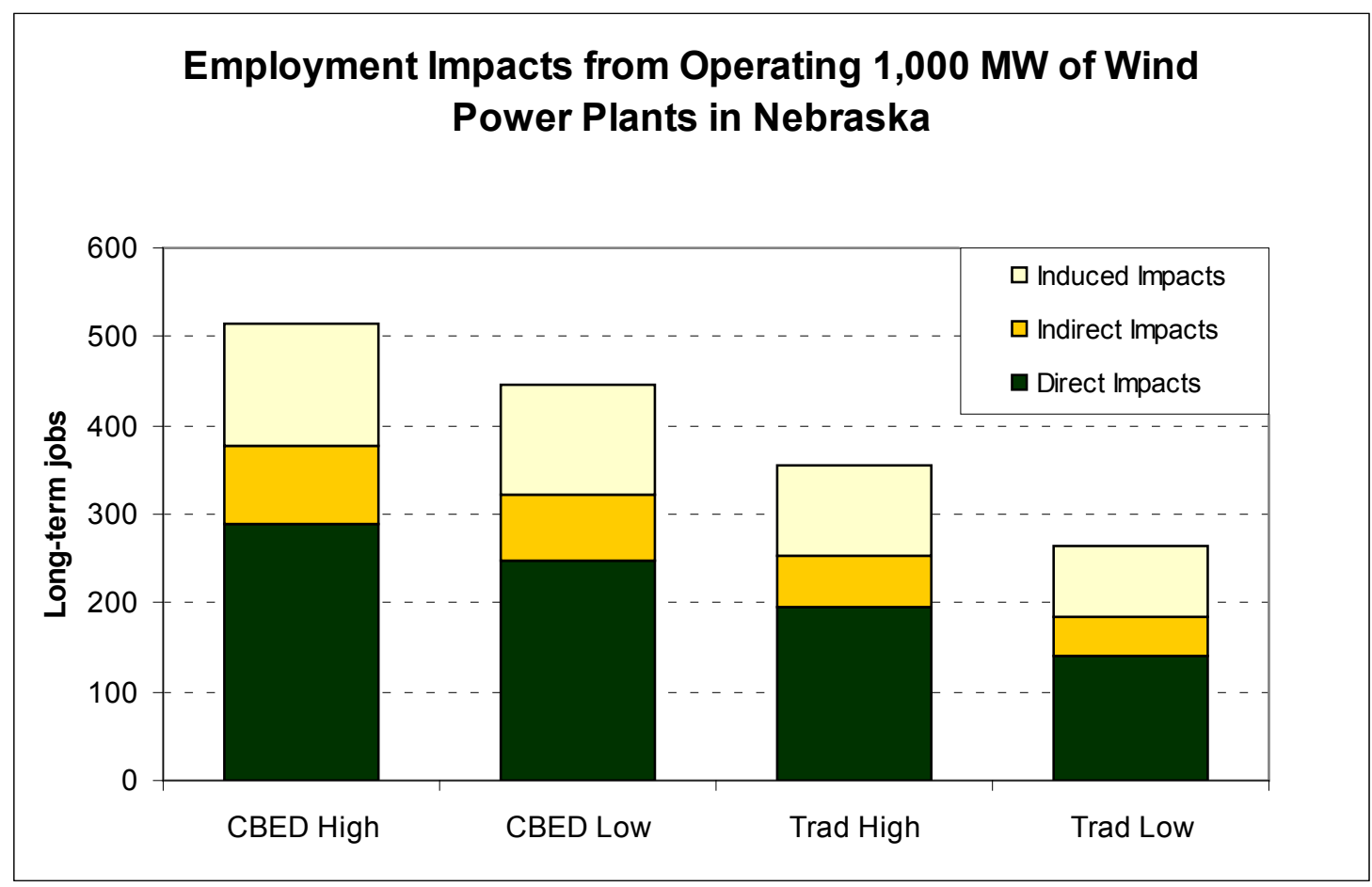

Figure 5. Long-term jobs resulting from operations of 1,000 MW of wind power

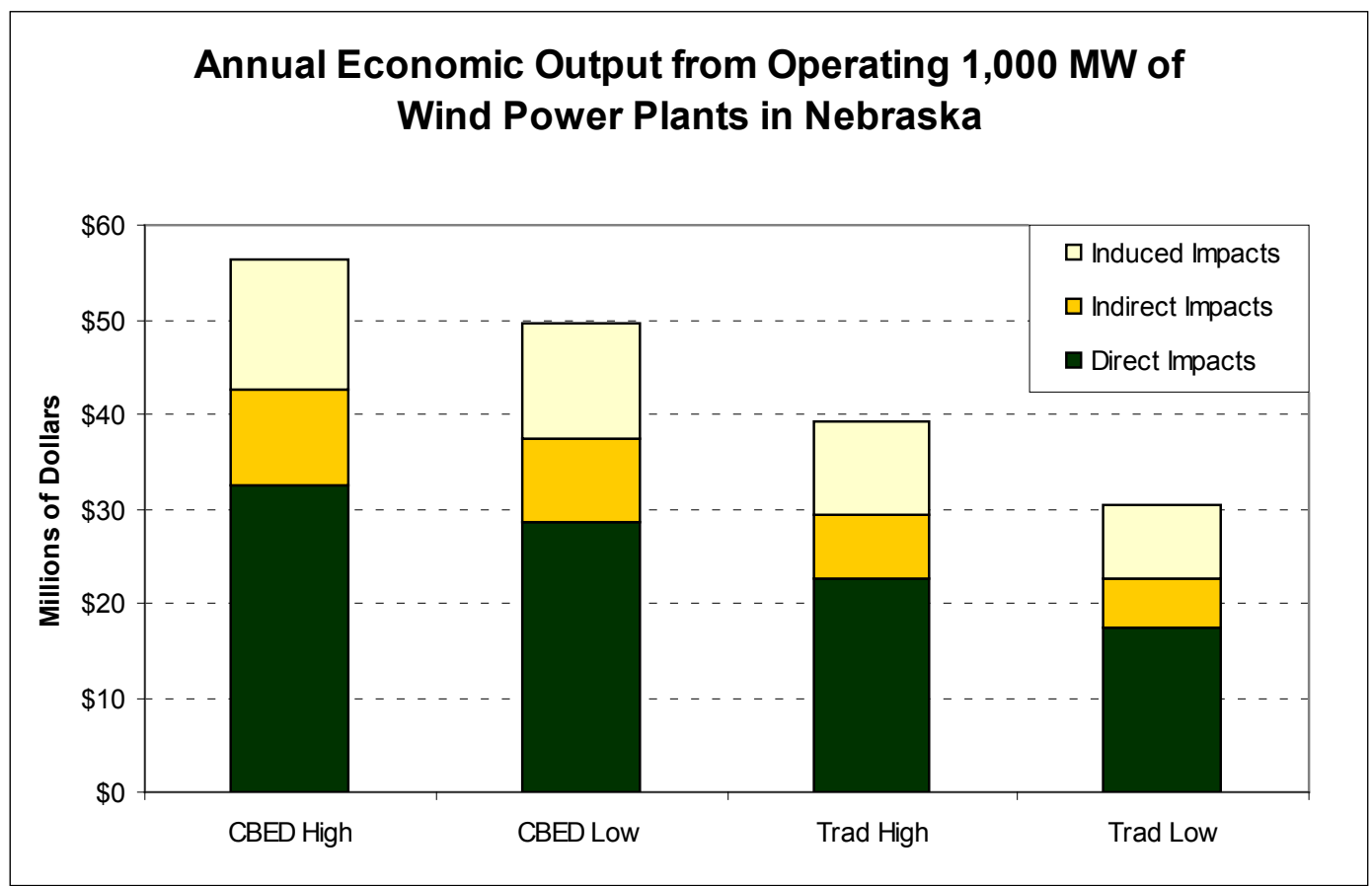

Figure 6. Annual economic output from operations and maintenance at wind power plants 


\section{Total Economic Impacts}

Assuming a total lifetime of 40 years (2011-2050) - from the beginning of construction until the final plant halts operations - average employment impacts from 7,800 MW are 1,600 to 2,925 fulltime jobs. Total economic output of 7,800 MW from construction and 20 years of operations is estimated at $\$ 7.8$ billion to $\$ 14.1$ billion. Assuming 20 years of operations, total land-lease payments are estimated to range from $\$ 547$ million to $\$ 641$ million and total tax contributions are expected to be on the order of $\$ 570$ million (Table 2).

Assuming a 2-year construction period and 20 years of operations, the average employment impact from building and operating 1,000 MW is 345 to 659 full-time jobs. Economic output from construction and 20 years of operations for 1,000 MW is estimated to range from $\$ 868$ million to $\$ 1,640$ million. Total land-lease and tax payments for 1,000 MW over the 20-year operations are estimated at $\$ 70$ million to $\$ 82$ million and $\$ 73$ million respectively (Table 2 ).

Table 2. Summary of Lifetime ${ }^{1}$ Impacts

\begin{tabular}{|c|c|c|c|c|}
\hline \multicolumn{3}{|c|}{ All dollar values are millions of 2008 constant dollars } & Low $^{2}$ & High $^{3}$ \\
\hline \multirow{5}{*}{ 7,800 MW } & \multirow{2}{*}{$\begin{array}{l}\text { Average Employment } \\
\text { Impact }\end{array}$} & Total Jobs Impact (Direct, Indirect, and Induced) & 1,600 & 2,925 \\
\hline & & Direct Wind Industry Jobs & 840 & 1,580 \\
\hline & \multirow{3}{*}{ Financial Impacts } & Total Economic Output & $\$ 7,800$ & $\$ 14,100$ \\
\hline & & Total Land-Lease Payments & $\$ 547$ & $\$ 641$ \\
\hline & & Total Property Tax Payments & \multicolumn{2}{|c|}{$\$ 570$} \\
\hline \multirow{5}{*}{$1,000 \mathrm{MW}$} & \multirow{2}{*}{$\begin{array}{l}\text { Average Employment } \\
\text { Impacts }\end{array}$} & Total Jobs Impact (Direct, Indirect, and Induced) & 345 & 659 \\
\hline & & Direct Wind Industry Jobs & 184 & 363 \\
\hline & \multirow{3}{*}{ Financial Impacts } & Total Economic Output & $\$ 868$ & $\$ 1,640$ \\
\hline & & Total Land Lease Payments & $\$ 70$ & $\$ 82$ \\
\hline & & Total Property Tax Payments & \multicolumn{2}{|c|}{$\$ 73$} \\
\hline \multicolumn{5}{|c|}{$\begin{array}{l}\text { Average annual impacts for } 7,800 \mathrm{MW} \text { assume a } 20 \text {-year construction period and } 20 \text { years of operations for a total } \\
\text { lifetime impact spread over } 40 \text { years. Average annual impacts for } 1,000 \mathrm{MW} \text { assume a } 2 \text {-year construction period and } 20 \\
\text { years of operations for a total impact spread over } 22 \text { years. } \\
\text { Low results represent the traditional development low scenario. } \\
{ }^{3} \text { High results represent the C-BED high scenario. }\end{array}$} \\
\hline
\end{tabular}

\section{Analysis and Conclusions}

Fundamentally, it is the investment in Nebraska from wind energy development and the financial returns that flow back to Nebraska businesses, individuals, and government that drive the state's economic development impacts from new wind power. Increasing reliance on local labor, materials, and manufacturing ${ }^{25}$ and increasing the level of Nebraska-based ownership in the projects would

\footnotetext{
${ }^{25}$ This analysis assumes that $7 \%$ of turbines (by cost) installed in Nebraska are Nebraska built in the low cases and $14 \%$ are built in Nebraska in the high case.
} 
increase economic development impacts. Likewise, reductions in the local investment and Nebraska financial returns would diminish the state's economic development impacts.

In addition to the share of the initial investment that remains in Nebraska, it is estimated that if the C-BED development model becomes dominant in Nebraska, approximately $26 \%$ of all wind energy production revenues will flow to Nebraska-based individuals and businesses as equity returns. ${ }^{26} \mathrm{In}$ contrast, if the traditional development model dominates, only $3.3 \%$ of project revenues are expected to remain in Nebraska. ${ }^{27}$ Such divergence is a large factor in explaining variability between the C$\mathrm{BED}$ results and the traditional scenario results.

One factor that could potentially reduce the impacts of wind power development is increased consolidation and specialization in the industry. This will diminish development impacts if it results in very high reliance on out-of-state contractors for construction and O\&M labor. Such a scenario is possible if Nebraska construction companies do not embrace wind development or if the development period is chaotic with periods of rapid and stagnant growth that do not facilitate the development of a skilled local labor force or encourage manufacturing investment. ${ }^{28}$ In addition, if project owners consolidate operations and routine monitoring of wind farms to centralized stations around the country and rely heavily on short-term contracted crews to perform unexpected maintenance, O\&M impacts could be decreased below the values presented in this analysis.

\footnotetext{
${ }^{26}$ Assuming $80 \%$ of the projects are C-BED, the minimum revenue stream for each C-BED project is $33 \%$.

${ }^{27}$ For the purpose of this analysis, local project revenues are modeled as a 9\% return on investment.

${ }^{28}$ This latter condition is symptomatic of the broader U.S. condition. Based on uncertainty regarding the PTC, investors have been hesitant to invest heavily in wind energy manufacturing. This has begun to change, but anecdotal evidence clearly indicates that sporadic growth is a barrier to manufacturing investment.
} 
However, there is also the possibility that Nebraska impacts could exceed those laid out in the high scenarios. Previous research shows that construction materials and wind turbine manufacturing are generally more instrumental in driving economic development impacts than where project-related labor is sourced (Lantz and Tegen 2008). As a result, an increase in Nebraska-based wind-turbinerelated manufacturing coupled with increased reliance on local materials would cause the economic development impacts to be higher than those projected in this analysis. Text Box 4 highlights the impacts that manufacturing is already producing in Nebraska and Iowa. Text Box 5 uses Iowa as a case study to demonstrate how significant the impact of local manufacturing can be. Further, if an increased number of Nebraska's projects utilize C-BED incentives or if C-BED projects exceed the minimum qualifications necessary to be granted C-BED status, this will also increase the share of project revenues that flow to Nebraska individuals and communities and increase in economic development impacts.

\section{Text Box 4: Economic Development and Manufacturing Impacts}

\section{In Nebraska:}

\section{Katana Summit}

Columbus, Nebraska

Tower Manufacturer

- Constructed a 250,000-square-foot manufacturing facility

- Began production in 2008 and expects to manufacture approximately 300 towers per year in 2008 and ramp up to 400 to 600 towers per year by 2010

- Plans to employ 100-120 workers at full production levels

- Represents an investment of \$20 million

\section{Examples from elsewhere:}

\section{TPI Composites \\ Newton, Iowa \\ Blade Factory}

- In October 2007, Newton lost 1,800 jobs when Maytag closed its manufacturing facility

- Less than 2 months later, TPI Composites chose Newton as the site for its blade-manufacturing facility

- The plant will employ about 500 workers at an average wage of $\$ 13.40$ an hour

- Newton, the state of Iowa, and Jasper County provided nearly $\$ 4$ million in incentives for TPI Composites to locate the facility in Newton

- The plant is expected to open in the summer of 2008

Compiled by F. Oteri, NREL (www.windpoweringamerica.gov)

Based on the added financial incentives associated with a qualifying C-BED project, the potential for reduced public opposition, and the increased protection from eminent domain, there are significant reasons to believe that without future policy changes the C-BED development model will become the dominant wind development model in Nebraska. If this occurs, the level of C-BED projects and C-BED impacts could exceed those that are estimated here.

In conclusion, the economic development impacts to Nebraska from wind power on the order of that expected under the DOE's report, 20\% Wind Energy by 2030, are estimated at $\$ 7.8$ billion to $\$ 14.1$ billion dollars in economic activity and an average of 1,600 to 2,925 full-time jobs between 2011 thru 2050. In addition, building 1,000 MW of wind can provide $\$ 870$ million to $\$ 1,640$ million in economic activity and provide jobs for an average of 345 to 649 people for the next 22 years. 
However, achieving the highest levels of economic development impacts results from increasing local ownership of wind power projects and attracting new wind power manufacturing to the state. In addition, maintaining a wind energy capable workforce and attracting new windrelated manufacturing is of a great benefit because of its ability to secure Nebraska economic benefits from development that occurs outside the state. However, the competitive nature of the wind industry suggests a supportive policy environment for wind energy in Nebraska will increase the likelihood that Nebraskans are able to capitalize on the economic development impacts described here.

\section{Text Box 5: The Role of Iowa's Manufacturing in Shaping Economic Development Impacts}

Iowa is a leading state in terms of installed wind power capacity. In addition, it is the leading state for large-scale wind power manufacturing. Presently, there are six major existing or planned manufacturing facilities in Iowa which, when completed, will have the capacity to supply more than 1,000 MW of turbine blades and turbine generator components. ${ }^{1}$ In addition, out of current proposed projects in Iowa, it is estimated that $13 \%$ have selected turbines that could be manufactured by facilities in the state. ${ }^{2}$ Based on this information, we developed three scenarios for Iowa that demonstrate the potential economic development impacts that in-state manufacturing can provide from Iowa's next 2,400 MW of wind power. The figure below highlights the results of local manufacturing on economic development.

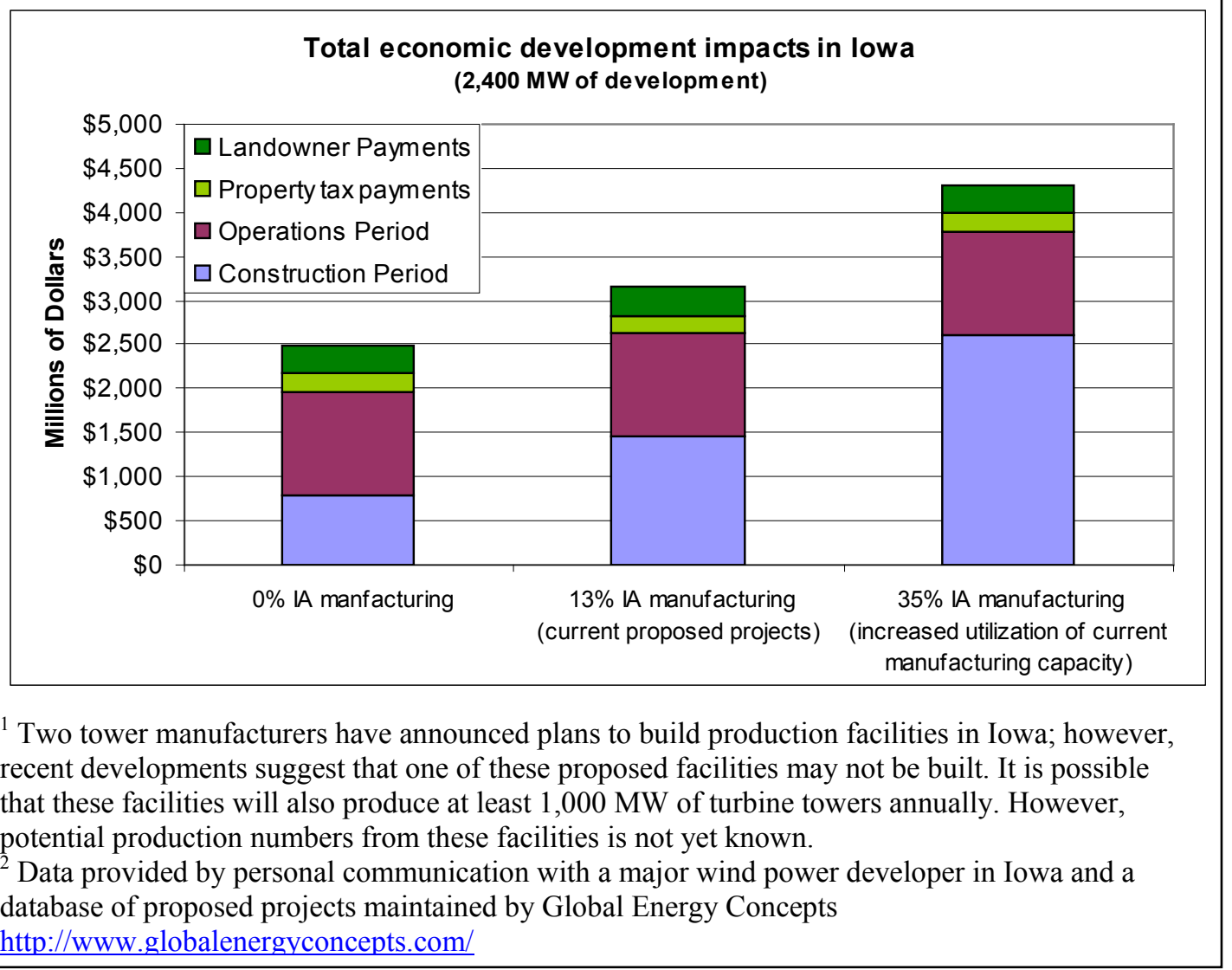




\section{Bibliography}

(2006). Stimulating Wind Energy in Nebraska's Panhandle. Wind Energy Survey Report. Panhandle Area Development District. (PADD). Gering, NE.

http://www.nepadd.com/Wind\%20Energy\%20Report.pdf Accessed October 15, 2008.

(2008) 20\% Wind Energy by 2030. DOE/GO-102008-2567.

http://20percentwind.org/20p.aspx?page=Report Accessed October 15, 2008.

Clendenin, J.; Belyeu, K.; (2008). U.S. Wind Energy Installations Surpass 20,000 Megawatts. Press Release. American Wind Energy Association. Washington D.C.

http://awea.org/newsroom/releases/Wind_Installations_Surpass_20K_MW_03Sept08.html Accessed October 15, 2008.

Lantz, E.; Tegen, S. (2008). Variables Affecting Economic Development of Wind Energy. NREL Report No. CP-500-43506. http://www.nrel.gov/docs/fy08osti/43506.pdf Accessed October 15, 2008.

Nebraska Revised Statues 77-2704.56 and Chapter 70.

http://uniweb.legislature.ne.gov/QS/laws.php?mode=show sta Accessed October 15, 2008.

O’Connell, R.; Pletka, R.; (2007). 20 Percent Wind Energy Penetration in the United States: A technical Analysis of the Energy Resource. Overland Park, KS: Black and Veatch.

http://20percentwind.org/Black_Veatch_20_Percent_Report.pdf Accessed June 9, 2008.

Real de Azua, C. (2008). Looming Expiration of Federal Incentive Threatens wind Power's Newfound Growth: AWEA Second Quarter Market Report. American Wind Energy Association.

Washington D.C.

http://awea.org/newsroom/releases/AWEA_Quarterly_Market_Report_080508.html Accessed October 15, 2008.

Wiser, R.; Barbose, G. (2008). Renewables Portfolio Standards in the United States. LBNL-154E. Berkelely, CA. Lawrence Berkeley National Laboratory. http://eetd.lbl.gov/ea/ems/reports/lbnl154e-revised.pdf Accessed October 15, 2008.

Wiser, R.; Bolinger, M. (2008). Annual Report on U.S. Wind power Installation, Cost, and Performance Trends: 2007. DOE/GO-102008-2590. Berkeley, CA. Lawrence Berkeley National Laboratory. http://www.nrel.gov/docs/fy08osti/43025.pdf Accessed June 9, 2008.

Wiser, R.; Bolinger, M.; Barbose, G. (2007). Using the Federal Production Tax Credit to Build a Durable Market for Wind Power in the United States. LBNL-63583. Berkeley, CA. Lawrence Berkeley National Laboratory. http://eetd.lbl.gov/ea/EMS/reports/63583.pdf Accessed October 15, 2008. 


\section{Appendix I: Detailed Modeling Methods}

To analyze the economic development impacts of wind power, literature reviews and interviews were conducted to obtain data for economic development impacts modeling. Applicable information was acquired from Nebraska electric industry contacts, state tax officials, wind power project developers, and press releases of proposed wind facilities. This information was compiled and utilized to develop the four scenarios considered in this report.

Acquired data were applied to the National Renewable Energy Laboratory's (NREL's) latest Jobs and Economic Development Impacts Wind (JEDI Wind) ${ }^{29}$ model to estimate economic development impacts of wind power development that could occur from development on the order of that expected under the DOE report 20\% Wind Energy by 2030 .

The JEDI model is an input-output model tailored to the wind industry and based on economic multiplier data (2006) from the Minnesota Implan Group (MIG). Economic development impacts are estimated based on the relationship between investment in windrelated industries and the respective changes in economic activity. Industry multipliers are based on a snapshot of the Nebraska economy in 2006 and reflect industry relationships at that time.

For the purpose of modeling project revenues expected to accrue from C-BED incentives, a $9 \%$ return on equity is assumed in both the high and low scenarios. Revenues are modeled as a return on equity investment with a repayment term of 20 years. Nebraska equity is considered to constitute $33 \%$ of project financing. For the purpose of modeling, the remaining $67 \%$ of project financing could be in the form of non-Nebraska equity or debt. In addition, it was assumed that $50 \%$ of revenues that flow to Nebraska entities were reinvested or spent in Nebraska. For additional information on specific inputs into the JEDI model, see Appendix IV.

These results represent the total economic development impacts resulting from wind development. They do not represent the net benefit of wind development relative to any other specific generation resource, nor do they incorporate costs, rate or integration, to electricity consumers.

${ }^{29}$ http://www.nrel.gov/analysis/jedi/about_jedi.html 


\section{Appendix II: Supplemental Discussion}

\section{Wind Energy and Public Power Expanded}

Nebraska's status as a public power state has provided electricity rates that are among the lowest in the country, and public power has served Nebraska residents successfully for many years. ${ }^{30}$ The state's Community-Based Energy Development (C-BED) legislation, signed into law in 2007, provides policy mechanisms that allow wind energy to support and reinforce public power's mandates.

C-BED legislation specifically addresses the two primary barriers to wind energy development that previously existed in Nebraska. First, public power, as a result of its taxexempt status, is not able to qualify for federal wind energy support in the form of the federal Production Tax Credit (PTC) ${ }^{31}$ As a result, wind power owned by Nebraska's public power utilities is less competitive with traditional power generation resources. Projects that qualify for the PTC are generally competitive with wholesale energy markets around the country (Wiser and Bolinger 2008). This conflicts with public power's leastcost mandate because it hinders the competitive nature of wind power. C-BED projects are owned and operated by taxable entities and therefore, are theoretically capable of providing power at rates that are competitive with prices observed at wholesale trading hubs.

Second, the vast majority of wind power development around the country has been carried out by Independent Power Producers (IPPs) who contract power sales with retailers through Power Production Agreements (PPAs). While IPPs selling power to Nebraska's public power districts would allow the public power retailers to capture the PTC, IPPs have been hesitant to invest in Nebraska due to legacy statutes that date back to Nebraska's transition to a $100 \%$ public power state. During this era, the legislature gave public power districts and municipalities the authority of eminent domain over privately owned power assets in order to move the state to public power. With these statutes still a part of the Nebraska code, IPPs have not been willing to undertake the potential risk of asset condemnation by Nebraska's public power districts (PADD 2006). However, C-BED legislation requires that electric suppliers in the state limit their power of eminent domain when they have contracted a PPA for 10 years or more from a C-BED project (Nebraska Revised Statutes 70-1909).

Further, as C-BED projects are shown to have enhanced economic development impacts, encourage Nebraskan ownership, and potentially reduce costs through additional state sales

\footnotetext{
${ }^{30}$ According to the U.S. Energy Information Administration (eia.doe.gov), the average retail price for electricity in Nebraska in 2006 was 6.07 cents/kWh (total electric industry). This places it well below the national average of 8.90 cents $/ \mathrm{kWh}$ and gives it the status of sixth-lowest retail electricity rate in the country. ${ }^{31}$ While there is a federal mechanism for support of wind power owned and operated by tax-exempt entities (the Renewable Energy Production Incentive), it has remained significantly underfunded and has not provided the support that the legislation allows for.
} 
and use tax exemptions, they support public power mandates of economic development and least-cost power production.

\section{Modeling and Analytical Considerations}

Modeling 7,800 MW of wind development over a 20-year period presents a variety of challenges. A primary challenge is forecasting how the wind industry will evolve and mature over this time period and estimating the ability of Nebraska labor, services, and materials to capture demand for wind development in the state. For this reason, the high and low scenarios for the two types of development models were developed.

The increased economic impacts that arise from C-BED projects are primarily the result of gross power sales revenues that flow to Nebraska residents and businesses. Simply requiring revenues from project operations to remain in-state provides a significant boost to economic development in the state. Additionally, because revenues from a successful wind project are required to go to Nebraska entities, they are also more likely to be reinvested and spent in Nebraska. Spending profits from energy sales in Nebraska further stimulates indirect and induced impacts from wind farm operation. These modeling efforts assume that $50 \%$ of project profits that flow to Nebraska residents and businesses are spent or reinvested in Nebraska.

Furthermore, in modeling of C-BED projects, it is assumed that projects are successful and profitable. In effect, payments to equity at an assumed interest rate are modeled as project expenditures, and such an approach requires a profitable project. It is also assumed that PPA negotiations take into consideration the tax credit benefit that is accrued by wind farms that qualify for the PTC. Therefore, the gross revenues from a PPA may not capture the full value of a wind power project. Regardless, all Nebraska-based entities that receive a portion of PPA revenues as individual equity holders receive a 9\% return on investment (ROI) annually. Nine percent is chosen as it represents a reasonable annual ROI for individuals and small business that may consider investing capital, labor, or services in a wind farm. Finally, it is assumed that project developers only meet the minimum requirements to qualify for $\mathrm{C}$-BED projects. In fact, developers may exceed these minimum expectations with the effect of increasing economic development impacts. In addition to accounting for PPA revenues in the C-BED model, a moderately increased reliance on local materials and services is incorporated. ${ }^{32}$

\footnotetext{
${ }^{32}$ This is due to the more active participation of local stakeholders and the potential for local ownership that may exercise a preference for local labor. However, in cases where private developers already utilize all available in-state resources, labor, and materials, this extra boost to local economies may not occur simply because the skills and resources do not exist. One possible example here is in consideration of turbine availability. In the current world of wind turbine scarcity, Nebraska developers may secure turbines from any company that can deliver them. However, in a less scarce turbine supply scenario, which we envision as the industry matures, developers may prefer Nebraska-manufactured equipment to reduce transportation costs. Nevertheless, if all Nebraska-manufactured equipment is directed elsewhere, neither C-BED projects nor traditionally developed projects will be capable of procuring locally manufactured equipment and therefore
} 
Constants throughout all scenarios include property tax payments and landowner leases. In addition, manufacturing tends to be correlated with demand for wind turbines rather than a specific development model. As a result, the high and low manufacturing parameters are the same in both the traditional and C-BED development models. During the O\&M period, both the high scenarios rely $100 \%$ on local labor. Generally, the high O\&M scenarios are similar because experience suggests that when feasible, even corporately developed and owned projects utilize as much local labor and materials as possible, simply because it is economically efficient. As a result, it is assumed that those materials that cannot be procured locally by corporate developers are unlikely to be procured by C-BED projects simply because they are unlikely to be available from local vendors. This includes services such as insurance or specialized wind turbine tools and parts. For additional information in regards to modeling inputs, see Appendix III.

\section{Manufacturing and Economic Development}

In Iowa, wind-turbine-related manufacturing is already producing large economic impacts. In contrast, Nebraska is only now beginning to experience the economic impacts of windenergy-related manufacturing with the June 2008 opening of the Katana Summit LLC manufacturing facility for wind turbine towers.

Manufacturing has an immense potential to increase the economic impacts that can accrue in Nebraska from building wind power both in Nebraska and the surrounding region. A few of the primary manufacturing opportunities include wind turbine blade manufacturing, tower manufacturing, and drive train assembly. These three categories of development represent the types of manufacturing facilities that have been rapidly expanding in Iowa, Colorado, and elsewhere. Iowa is expected to provide each of these specific services in the near future and has virtually achieved a full supply chain of major wind turbine components. In addition, wind turbines (especially the drivetrains) consist of numerous subcomponents, including bearings, gearboxes, and power generators (each consisting of multiple machined subcomponents). As a result, the opportunity for wind turbine manufacturing presents an array of possibilities.

\section{Caveat}

This analysis is based on the construction of a specific capacity of wind power in Nebraska. Fundamentally, this analysis only applies if this development occurs. Developing this magnitude of wind power may require new policy, at either the state or federal level, and is very likely to require new transmission. No presumptions or recommendations about how to achieve this specific installation capacity are made. These results merely represent what is estimated to be the impacts if Nebraska builds this specific volume of wind power. Any changes or deviations from the actual inputs summarized in Appendix IV will change the results.

no differences will exist in this parameter regardless of preferences for or against Nebraska-based manufacturing. 


\section{Appendix III: JEDI Model Inputs}

Table 4. Capacity Factors and Cost Inputs*

\begin{tabular}{|c|c|c|c|}
\hline & $\begin{array}{c}\text { Capital Costs } \\
(2008 \$)\end{array}$ & $\begin{array}{c}\text { Capacity } \\
\text { Factor }\end{array}$ & $\begin{array}{c}\text { O\&M Cost } \\
\$ / \mathrm{kW}(2008 \$)\end{array}$ \\
\hline $\mathbf{2 0 1 2}$ & 1717 & $42.2 \%$ & 24.86 \\
\hline $\mathbf{2 0 1 4}$ & 1717 & $43.3 \%$ & 25.25 \\
\hline $\mathbf{2 0 1 6}$ & 1675 & $43.8 \%$ & 23.97 \\
\hline $\mathbf{2 0 1 8}$ & 1675 & $44.1 \%$ & 24.05 \\
\hline $\mathbf{2 0 2 0}$ & 1632 & $44.1 \%$ & 22.85 \\
\hline $\mathbf{2 0 2 2}$ & 1632 & $44.1 \%$ & 22.85 \\
\hline $\mathbf{2 0 2 4}$ & 1632 & $44.1 \%$ & 22.85 \\
\hline $\mathbf{2 0 2 6}$ & 1632 & $44.1 \%$ & 22.85 \\
\hline $\mathbf{2 0 2 8}$ & 1632 & $44.1 \%$ & 22.85 \\
\hline $\mathbf{2 0 3 0}$ & 1546 & $44.1 \%$ & 22.24 \\
\hline \multicolumn{4}{|c|}{} \\
*All cost values are 2008 dollars and are derived from O'Connell \\
and Pletka 2007; O\&M costs include fixed and variable costs \\
\hline
\end{tabular}

Table 5. Landowner and Property Tax Payments

\begin{tabular}{|l|c|c|}
\hline & Low (2008 \$/MW) & High (2008 \$/MW) \\
\hline Property Tax (\$/MW) & & \\
\hline Landowner Lease Payments (\$/MW) & 3,648 & 3,648 \\
\hline
\end{tabular}

Table 6. C-BED Modeling Implications

\begin{tabular}{|l|c|c|}
\hline & $\begin{array}{c}\text { Traditional } \\
\text { Development }\end{array}$ & C-BED Projects \\
\hline Development that Qualifies as C-BED & $10 \%$ & $80 \%$ \\
\hline Assumed C-BED Project Rate of Return & $9 \%$ & $9 \%$ \\
\hline $\begin{array}{l}\text { Percentage of PPA Gross Revenues to } \\
\text { Qualifying Nebraska Entities }\end{array}$ & $33 \%$ & $33 \%$ \\
\hline
\end{tabular}


Table 7. Percentage of Project Expenditures Directed to Nebraska

\begin{tabular}{|c|c|c|c|c|}
\hline & \multicolumn{2}{|c|}{ Traditional Development Model } & \multicolumn{2}{|c|}{ C-BED Development Model } \\
\hline & Low & High & Low & High \\
\hline \multicolumn{5}{|l|}{ Construction Materials } \\
\hline \begin{tabular}{l|l} 
& Raw Materials \\
\end{tabular} & $65 \%$ & $95 \%$ & $80 \%$ & $100 \%$ \\
\hline Transformer & $0 \%$ & $0 \%$ & $0 \%$ & $0 \%$ \\
\hline Electrical Supplies & $10 \%$ & $50 \%$ & $30 \%$ & $70 \%$ \\
\hline HV Line Extension & $10 \%$ & $50 \%$ & $30 \%$ & $70 \%$ \\
\hline \multicolumn{5}{|l|}{ Construction Labor } \\
\hline \begin{tabular}{l|l} 
& Foundation \\
\end{tabular} & $100 \%$ & $100 \%$ & $100 \%$ & $100 \%$ \\
\hline Turbine Assembly and Erection & $30 \%$ & $80 \%$ & $60 \%$ & $90 \%$ \\
\hline Electrical & $30 \%$ & $50 \%$ & $50 \%$ & $70 \%$ \\
\hline Management & $10 \%$ & $40 \%$ & $60 \%$ & $80 \%$ \\
\hline \multicolumn{5}{|l|}{ Turbine Equipment and Manufacturing } \\
\hline \begin{tabular}{l|l} 
Turbine \\
\end{tabular} & $0 \%$ & $0 \%$ & $0 \%$ & $0 \%$ \\
\hline Blades & $15 \%$ & $35 \%$ & $15 \%$ & $35 \%$ \\
\hline Towers & $25 \%$ & $50 \%$ & $25 \%$ & $50 \%$ \\
\hline \multicolumn{5}{|l|}{ Other Construction Costs } \\
\hline \begin{tabular}{l|l|} 
& HV Sub/Interconnection \\
\end{tabular} & $80 \%$ & $100 \%$ & $80 \%$ & $100 \%$ \\
\hline Engineering & $15 \%$ & $50 \%$ & $30 \%$ & $70 \%$ \\
\hline Legal Services & $50 \%$ & $75 \%$ & $75 \%$ & $100 \%$ \\
\hline Land Easements & $100 \%$ & $100 \%$ & $100 \%$ & $100 \%$ \\
\hline Site Certificate/Permitting & $100 \%$ & $100 \%$ & $100 \%$ & $100 \%$ \\
\hline $\begin{array}{l}\text { Percentage of Total Construction Investment } \\
\text { that Remains in Nebraska }\end{array}$ & $13.4 \%$ & $23.8 \%$ & $15.1 \%$ & $24.9 \%$ \\
\hline \multicolumn{5}{|l|}{ O\&M Personnel } \\
\hline Field Salaries & $80 \%$ & $100 \%$ & $80 \%$ & $100 \%$ \\
\hline Administrative & $50 \%$ & $100 \%$ & $75 \%$ & $100 \%$ \\
\hline Management & $80 \%$ & $100 \%$ & $100 \%$ & $100 \%$ \\
\hline \multicolumn{5}{|l|}{ O\&M Materials } \\
\hline \begin{tabular}{l|l} 
& Vehicles \\
\end{tabular} & $100 \%$ & $100 \%$ & $100 \%$ & $100 \%$ \\
\hline Misc. Services & $50 \%$ & $80 \%$ & $60 \%$ & $80 \%$ \\
\hline Fees \& Licenses & $100 \%$ & $100 \%$ & $100 \%$ & $100 \%$ \\
\hline Utilities & $100 \%$ & $100 \%$ & $100 \%$ & $100 \%$ \\
\hline Insurance & $0 \%$ & $0 \%$ & $0 \%$ & $0 \%$ \\
\hline Transport Fuel & $100 \%$ & $100 \%$ & $100 \%$ & $100 \%$ \\
\hline Tools and Basic Supplies & $30 \%$ & $70 \%$ & $40 \%$ & $70 \%$ \\
\hline Spare Parts & $0 \%$ & $6 \%$ & $0 \%$ & $9 \%$ \\
\hline $\begin{array}{l}\text { Percentage of Total O\&M Spending that } \\
\text { Remains in Nebraska }\end{array}$ & $36.6 \%$ & $57.1 \%$ & $42.0 \%$ & $57.5 \%$ \\
\hline
\end{tabular}




\section{Appendix IV: Detailed Results for Traditional Low and C-BED High scenarios (1,000 MW and 7,800 MW)}

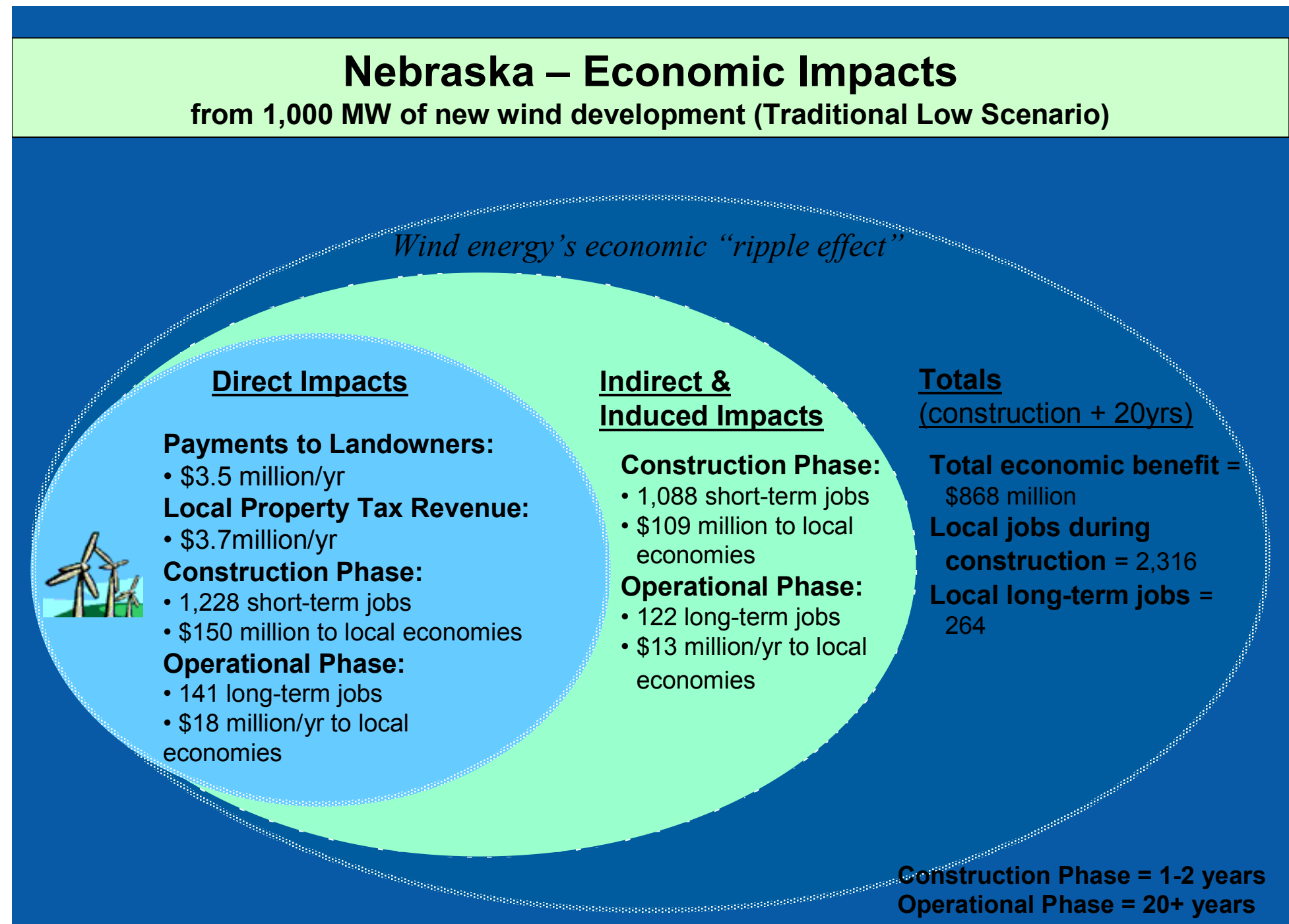




\section{Nebraska - Economic Impacts from 1,000 MW of new wind development (C-BED High Scenario)}

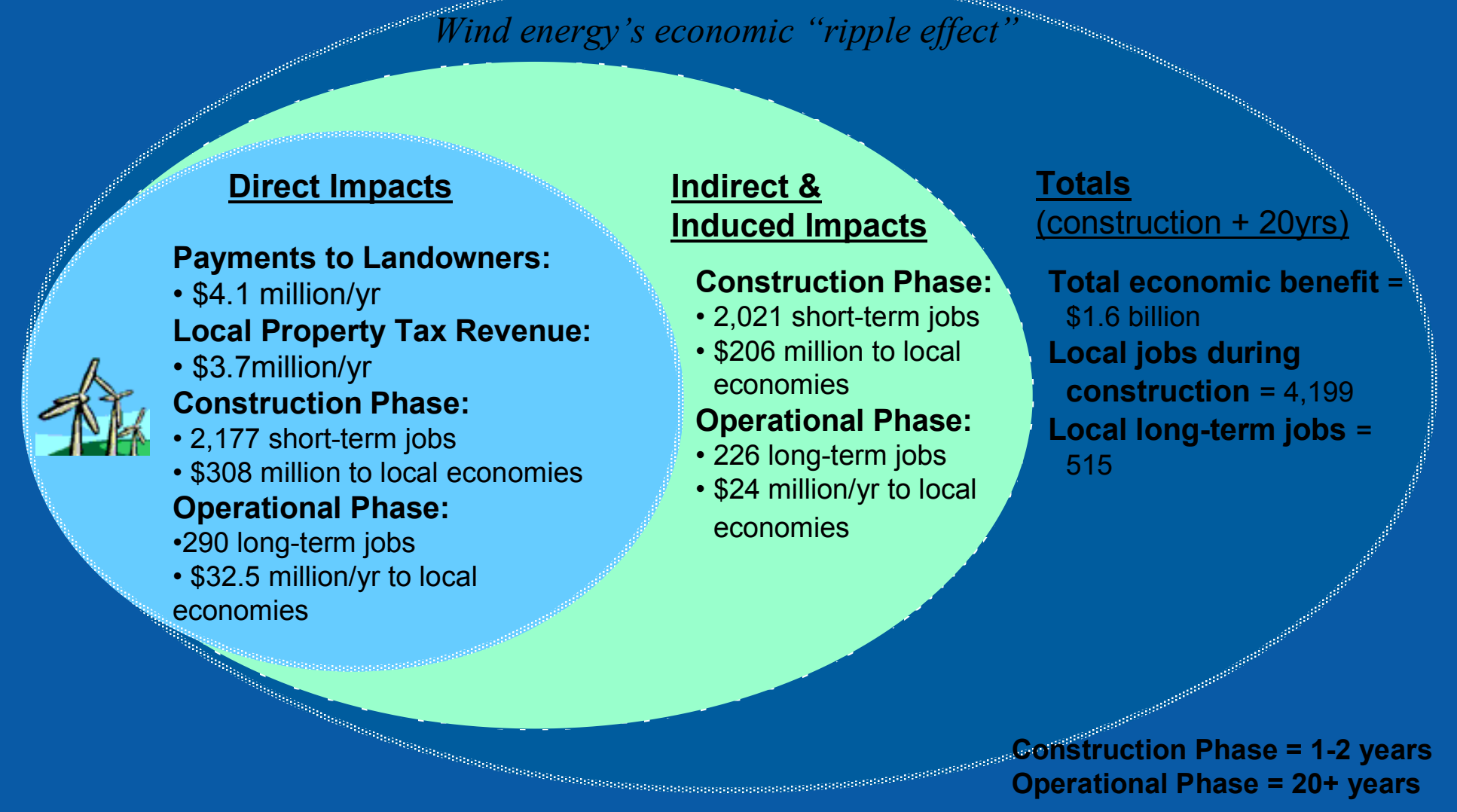




\section{Nebraska - Economic Impacts \\ from 7,800 MW of new wind development (Traditional Low Scenario)}

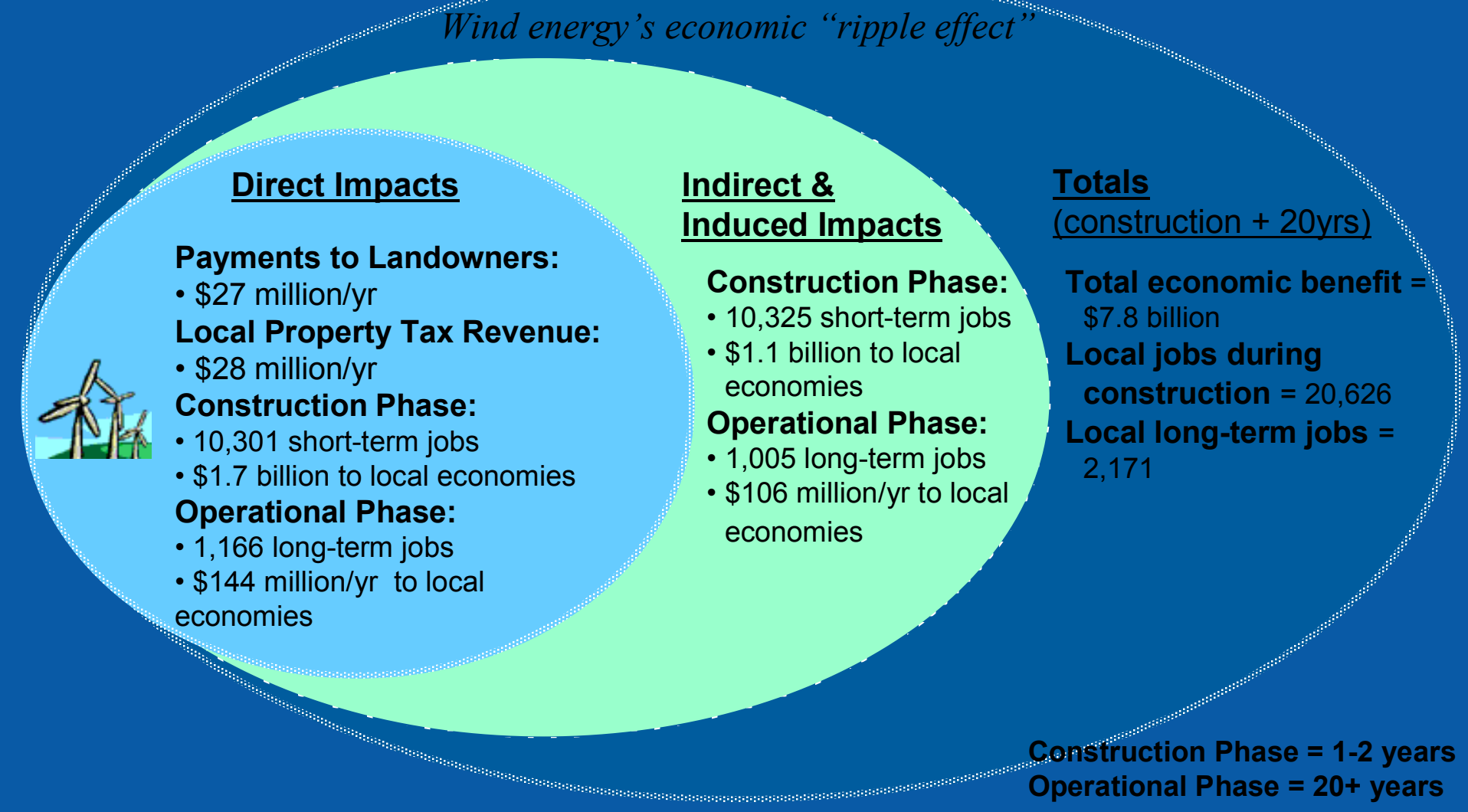




\section{Nebraska - Economic Impacts from 7,800 MW of new wind development (C-BED High Scenario)}

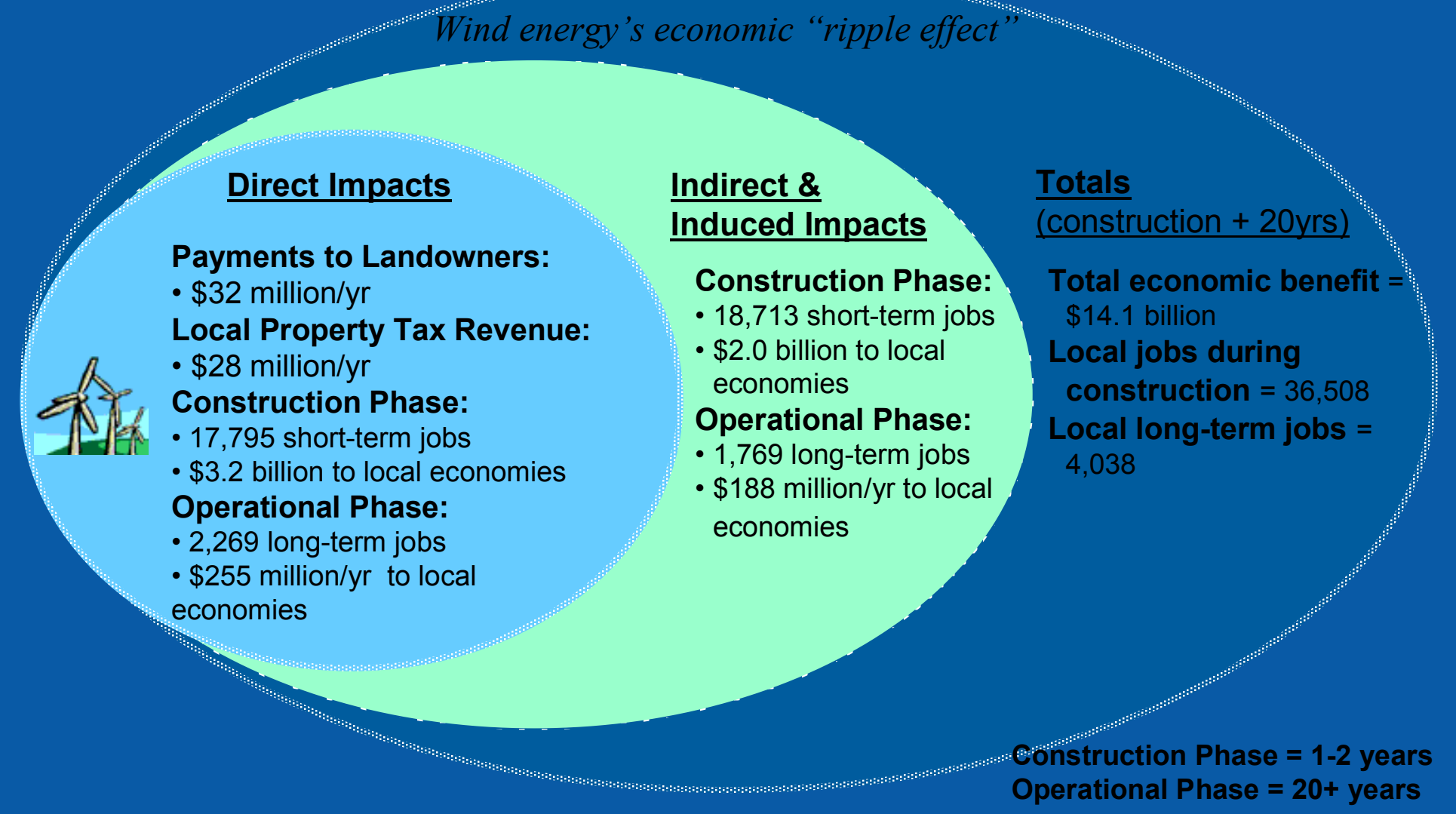




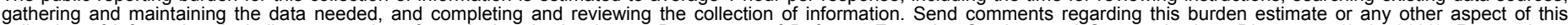

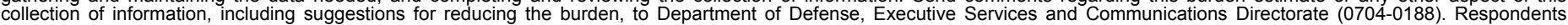

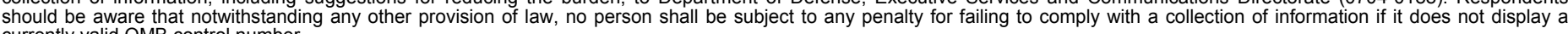

PLEASE DO NOT RETURN YOUR FORM TO THE ABOVE ORGANIZATION.

\begin{tabular}{l|l|l|l} 
1. REPORT DATE $(D D-M M-Y Y Y Y)$ & 2. & REPORT TYPE & 3. DATES COVERED (FrOm - TO)
\end{tabular}

Revised June 2009

Technical Report

4. TITLE AND SUBTITLE

Economic Development Benefits from Wind Energy in Nebraska:

A Report for the Nebraska Energy Office (Revision)

5a. CONTRACT NUMBER

DE-AC36-08-GO28308

5b. GRANT NUMBER

5c. PROGRAM ELEMENT NUMBER

6. AUTHOR(S)

E. Lantz

5d. PROJECT NUMBER

NREL/TP-500-44344

5e. TASK NUMBER

WER9.8501

5f. WORK UNIT NUMBER
7. PERFORMING ORGANIZATION NAME(S) AND ADDRESS(ES)

National Renewable Energy Laboratory

1617 Cole Blvd.

Golden, CO 80401-3393
8. PERFORMING ORGANIZATION

REPORT NUMBER

NREL/TP-500-44344

9. SPONSORING/MONITORING AGENCY NAME(S) AND ADDRESS(ES)

10. SPONSOR/MONITOR'S ACRONYM(S) NREL

11. SPONSORING/MONITORING AGENCY REPORT NUMBER

12. DISTRIBUTION AVAILABILITY STATEMENT

National Technical Information Service

U.S. Department of Commerce

5285 Port Royal Road

Springfield, VA 22161

13. SUPPLEMENTARY NOTES

14. ABSTRACT (Maximum 200 Words)

This report focuses on the economic development impacts estimated from building and operating 7,800 MW of new wind power in Nebraska. This level of development is on the scale envisioned in the Department of Energy (DOE) report $20 \%$ Wind Energy by 2030 . A practical first step to building 7,800 of wind is completing $1,000 \mathrm{MW}$. We also include the estimated economic impacts to Nebraska from building 1,000 MW of wind power.

Our primary analysis indicates that the development and construction of approximately 7,800 MW of wind energy in Nebraska by 2030 will support 20,600 to 36,500 annual full-time equivalents (AFTE). In addition, operating the full 7,800 MW of wind energy could support roughly 2,000 to 4,000 full-time workers throughout the operating life of the wind facilities (LFTE). Nebraska's economy is estimated to see an average annual boost in economic activity ranging from \$140 million to \$260 million solely from construction and development related activities between 2011 and 2030 . An additional boost of $\$ 250$ - $\$ 442$ million annually is estimated from operating 7,800 MW of wind capacity.

15. SUBJECT TERMS

wind energy; economic development; economic development benefits; Nebraska; jobs; JEDI; Jobs and Economic Development Impacts model

16. SECURITY CLASSIFICATION OF:

\begin{tabular}{|l|l|l|}
\hline $\begin{array}{c}\text { a. REPORT } \\
\text { Unclassified }\end{array}$ & $\begin{array}{c}\text { b. ABSTRACT } \\
\text { Unclassified }\end{array}$ & $\begin{array}{c}\text { c. THIS PAGE } \\
\text { Unclassified }\end{array}$ \\
\hline
\end{tabular}

19a. NAME OF RESPONSIBLE PERSON

19b. TELEPHONE NUMBER (Include area code) 